Toxicon

May 2016, Volume 114, Pages 16-27

http://dx.doi.org/10.1016/j.toxicon.2016.02.011

http://archimer.ifremer.fr/doc/00314/42521/

(c) 2016 Elsevier Ltd. All rights reserved.

\title{
Algal toxin profiles in Nigerian coastal waters (Gulf of Guinea) using passive sampling and liquid chromatography coupled to mass spectrometry
}

\author{
Zendong Suzie Zita ${ }^{1,3,{ }^{*}}$, Kadiri Medina ${ }^{2}$, Herrenknecht Christine ${ }^{3}$, Nézan Elisabeth ${ }^{4}$, \\ Mazzeo Antonia ${ }^{5}$, Hess Philipp ${ }^{1}$
}

${ }^{1}$ Ifremer, Laboratoire Phycotoxines, Rue de l'lle d'Yeu, 44311 Nantes, France

2 Department of Plant Biology and Biotechnology, University of Benin, Benin City, Nigeria

3 LUNAM, Université de Nantes, MMS EA2160, Faculté de Pharmacie, 9 rue Bias, 44035 Nantes, France

${ }^{4}$ Ifremer, Station de Biologie Marine, BP 40537, F-29185 Concarneau Cedex, France

${ }^{5}$ Dipartimento di Farmacia, Università degli Studi di Napoli Federico II, via D. Montesano 49, 80131

Napoli, Italiy

*Corresponding author : Zita Zendong, email address : zita.zendong@ifremer.fr

\begin{abstract}
:
Algal toxins may accumulate in fish and shellfish and thus cause poisoning in consumers of seafood. Such toxins and the algae producing them are regularly surveyed in many countries, including Europe, North America, Japan and others. However, very little is known regards the occurrence of such algae and their toxins in most African countries. This paper reports on a survey of phytoplankton and algal toxins in Nigerian coastal waters.
\end{abstract}

Seawater samples were obtained from four sites for phytoplankton identification, on three occasions between the middle of October 2014 and the end of February 2015 (Bar Beach and Lekki in Lagos State, Port Harcourt in Rivers State and Uyo in Akwa Ibom State). The phytoplankton community was generally dominated by diatoms and cyanobacteria; however several species of dinoflagellates were also identified: Dinophysis caudata, Lingulodinium polyedrum and two benthic species of Prorocentrum.

Passive samplers (containing Diaion ${ }^{\circledR}$ HP-20 resin) were deployed for several 1-week periods on the same four sites to obtain profiles of algal toxins present in the seawater. Quantifiable amounts of okadaic acid (OA) and pectenotoxin 2 (PTX2), as well as traces of dinophysistoxin 1 (DTX1) were detected at several sites. Highest concentrations $\left(60 \mathrm{ng} \mathrm{OA} \mathrm{g}^{-1} \mathrm{HP}-20\right.$ resin) were found at Lekki and Bar Beach stations, which also had the highest salinities. Non-targeted analysis using full-scan high resolution mass spectrometry showed that algal metabolites differed from site to site and for different sampling occasions. Screening against a marine natural products database indicated the potential presence of cyanobacterial compounds in the water column, which was also consistent with phytoplankton analysis. 
During this study, the occurrence of the marine dinoflagellate toxins OA and PTX2 has been demonstrated in coastal waters of Nigeria, despite unfavourable environmental conditions, with regards to the low salinities measured. Hence shellfish samples should be monitored in future to assess the risk for public health through accumulation of such toxins in seafood.

Keywords : Dinoflagellates, Dinophysis, phycotoxins, untargeted analysis, phytoplankton 


\section{INTRODUCTION}

Toxins from marine micro-algae frequently accumulate in seafood, including fish and shellfish, and maximum concentrations for such toxins have therefore been regulated at global and regional levels (DeGrasse and Martinez-Diaz, 2012; Hess, 2012; Lawrence et al., 2011; Suzuki and Watanabe, 2012). As fisheries have only limited potential to increasingly contribute to the global food supply, it is expected that any growth in seafood supply will have to come from aquaculture. Therefore, it is important to investigate the potential of coastal areas for seafood production, and also the risks associated with such production. In terms of public health risks, those originating from harmful algal blooms are particularly common in many parts of the world and must therefore be assessed relatively early on in any survey for aquaculture feasibility.

To our knowledge, no algal toxins have been reported in coastal waters of central Western Africa, except one preliminary report on potentially toxic fish in Cameroon (Bienfang et al., 2008). The southernmost records of algal toxins in Northern Africa are from the Moroccan coastline where an official monitoring program is in place (Abouabdellah et al., 2008; Taleb et al., 2003). Lipophilic shellfish toxins were shown to accumulate in mussels, cockles, oysters and solen, causing poisoning in the Dakhla region, i.e. the South Atlantic Moroccan coast (Abouabdellah et al., 2011). Toxins of the okadaic acid (OA) group, i.e. OA and dinophysistoxins (DTXs) and their associated esters were the agents responsible for those shellfish poisoning events, attributable to the presence of several potentially toxic species of Dinophysis. Taleb et al. (2006) also were the first to report the presence of azaspiracids in mussels, in Morocco.

In southern parts of Africa, regular monitoring is in place in South Africa and Namibia. Production of saxitoxin (STX) off the west coast of South Africa has been attributed to Alexandrium catenella (Pitcher and Calder, 2000; Pitcher et al., 2001). Fawcett et al. (2006) have developed and deployed a bio-optical buoy for monitoring HABs in the southern Benguela Current region off South Africa. These buoys have proved their efficiency in providing both real-time and time-series data, giving interesting information on the occurrence of Prorocentrum triestinum in the region. The northernmost records of algal toxins in the southern African region are from Angola (Blanco et al., 2010; Vale et al., 2009). 
Phytoplankton surveys in Nigeria by one of the authors have reported non-toxin producing as well as potentially toxic algae including Prorocentrum micans, Protoperidinium depressum, Prorocentrum mite, Dinophysis caudata, Peridinium gatunense, P. cinctum, Gymnodinium fuscum and an array of Ceratium species (Kadiri, 1999, 2001, 2002, 2006a, b, 2011). Previous studies by other authors also showed sporadic occurrences of D. caudata, Protoperidinium depressum, P. diabolus, Prorocentrum micans, Noctiluca scintillans in Lagos Lagoon (Nwankwo, 1991, 1997). A recent report additionally recorded Lingulodinium polyedrum, Prorocentrum minimum, . sigmoides and Scrippsiella trochoidea in Lagos, Cross Rivers and Delta States (Ajuzie and Houvenaghel, 2009).

As potentially toxic algae have repeatedly been reported from Nigerian coastal waters this study attempted to verify whether algal toxins actually do occur in Nigerian waters. Since there was no algal culturing facility available on site, and as many dinoflagellates are difficult to bring into culture, in particular Dinophysis, we have opted for an indirect approach based on passive sampling of algal toxins in Nigerian coastal waters. This approach had been introduced for monitoring of toxins by MacKenzie et al. (2004). We have focussed on regulated lipophilic toxins known to cause problems in terms of public health but have also used in parallel an approach for untargeted analysis based on high-resolution mass spectrometry as previously described (Zendong et al., 2015).

\section{MATERIALS AND METHODS}

\subsection{Chemicals, reagents and sorbent materials}

Certified standard solutions of okadaic acid (OA), domoic acid (DA), dinophysistoxins (DTX1, DTX2), 13-desmethyl spirolide C (13-desmeSPX-C), pectenotoxin 2 (PTX2), gymnodimine A (GYMA), azaspiracids (AZA1,-2 and -3), yessotoxin (YTX) and homo-yessotoxin (homo-YTX) were obtained from the National Research Council in Halifax, Canada. HPLC grade methanol and acetonitrile as well as ammonium formate and formic acid (98\%) were acquired from AtlanticLabo (Bordeaux, France) and Sigma Aldrich (Steinheim, Germany). Deionized water was produced inhouse to $18 \mathrm{M} \Omega \mathrm{cm}^{-1}$ quality, using a Milli-Q integral 3 system (Millipore). For analyses with the high resolution mass spectrometry instrument, acetonitrile and water of LC/MS grade were obtained from Fischer Scientific (Illkirch, France). For passive sampler devices, Diaon ${ }^{\circledR}$ HP-20 polymeric resin was purchased as bulk resin from Sigma-Aldrich and $12 \mathrm{~mL}$ capacity polypropylene 2 frits-Reservoirs were from Agilent Technologies.

Brucine-sulfanilic acid reagent was prepared by dissolving $1 \mathrm{~g}$ brucine sulfate $\left[\left(\mathrm{C}_{23} \mathrm{H}_{26} \mathrm{~N}_{2} \mathrm{O}_{4}\right)_{2}\right.$ $\left.\mathrm{H}_{2} \mathrm{SO}_{4}, 7 \mathrm{H}_{2} \mathrm{O}\right]$ and $0.1 \mathrm{~g}$ sulfanilic acid $\left(\mathrm{NH}_{2} \mathrm{C}_{6} \mathrm{H}_{4} \mathrm{SO}_{3} \mathrm{H}, \mathrm{H}_{2} \mathrm{O}\right)$ into $70 \mathrm{ml}$ of hot distilled water. Concentrated hydrochloric acid $(3 \mathrm{~mL})$ was further added and this mixture was cooled, mixed and then 
diluted to $100 \mathrm{~mL}$ with distilled water. The final mixture was stored in a dark bottle at $5{ }^{\circ} \mathrm{C}$. For ascorbic acid, the ready-made PhosVer 3 Hach $^{\mathrm{TM}}$ was used.

\subsection{Study area}

The study area (Figure 1), i.e. the Nigerian coastal area, is situated in the Guinea Current Large Marine Ecosystem, in the Gulf of Guinea. There are two main seasons in the deploying sites: the rainy (wet) season spanning from May to October and the dry season from November to April. The area is influenced by coastal upwelling which occurs seasonally along the northern and eastern coasts. There are two (major and minor) upwelling seasons. Those seasons occur annually with differing duration and intensities off Ghana and Cote d'Ivoire, in the central part of the large marine ecosystem. The major upwelling season occurs from June to September and transient upwelling events are from January to March (Ibe and Ajayi, 1985).

The coastline of Nigeria is approximately $853 \mathrm{~km}$ long between latitude $4^{\circ} 10^{\prime}$ to $6^{\circ} 20^{\prime} \mathrm{N}$ and longitude $2^{\circ} 45^{\prime}$ to $8^{\circ} 35^{\prime}$ E. The Nigerian coastal area is low-lying of not more than $3.0 \mathrm{~m}$ above sea level, generally covered by fresh water swamp, mangrove swamp, lagoonal mashes, tidal channels, beach ridges and sand bars (Dublin-Green et al., 1997).

The Nigerian coast is composed of four distinct geomorphological units namely: the Barrier-Lagoon complex; the Mud coast; the Arcuate Niger delta; and the Strand coast (Ibe, 1988). The vegetation of the Nigerian coastal area is characterised by mangrove forests, brackish swamp forests and rain forests. The coastal zone is richly endowed with a variety of mineral resources, including oil and gas. The four selected sites are located in the Gulf of Guinea (Atlantic Ocean), two in the Bight of Bonny to the East (Arcuate Niger delta) and two in the Bight of Benin to the West (outside the Barrier-lagoon complex).

Seawater sampling for nutrients and for phytoplankton analysis, as well as passive sampling were carried out at sites and dates as listed in Table 1.

Table 1: Sampling sites and dates for water and toxin analysis (date format: $\mathrm{dd} / \mathrm{mm} / \mathrm{yy}$ ) 
ACCEPTED MANUSCRIPT

\begin{tabular}{|c|c|c|c|c|}
\hline $\begin{array}{c}\text { Sampling } \\
\text { site }\end{array}$ & Latitude & Longitude & $\begin{array}{c}\text { Dates for water } \\
\text { sampling }\end{array}$ & $\begin{array}{c}\text { Dates for passive } \\
\text { sampling }\end{array}$ \\
\hline Bar Beach & N $6^{\circ} 25.340^{\prime}$ & E $3^{\circ} 26.189^{\prime}$ & $\begin{array}{c}18 / 10 / 14,02 / 02 / 15 \\
21 / 02 / 15\end{array}$ & $\begin{array}{l}\text { 18/10/14, 08/11/14, } \\
07 / 02 / 15,28 / 02 / 15\end{array}$ \\
\hline Lekki & $N 6^{\circ} 25.256^{\prime}$ & Е $3^{\circ} 32.180$ & $21 / 02 / 15$ & $08 / 11 / 14,28 / 02 / 15$ \\
\hline $\begin{array}{c}\text { Port } \\
\text { Harcourt }\end{array}$ & $\mathrm{N} 4^{\circ} 41.828^{\prime}$ & E $7^{\circ} 10.706^{\prime}$ & $29 / 01 / 15,22 / 02 / 15$ & $04 / 02 / 15,28 / 02 / 15$ \\
\hline Uyo & $\mathrm{N} 4^{\circ} 33.203^{\prime}$ & E $8^{\circ} 00.202^{\prime}$ & $\begin{array}{c}17 / 10 / 14,28 / 01 / 15, \\
23 / 02 / 15\end{array}$ & $\begin{array}{l}18 / 10 / 14,07 / 11 / 14 \\
03 / 02 / 15,25 / 02 / 15\end{array}$ \\
\hline
\end{tabular}

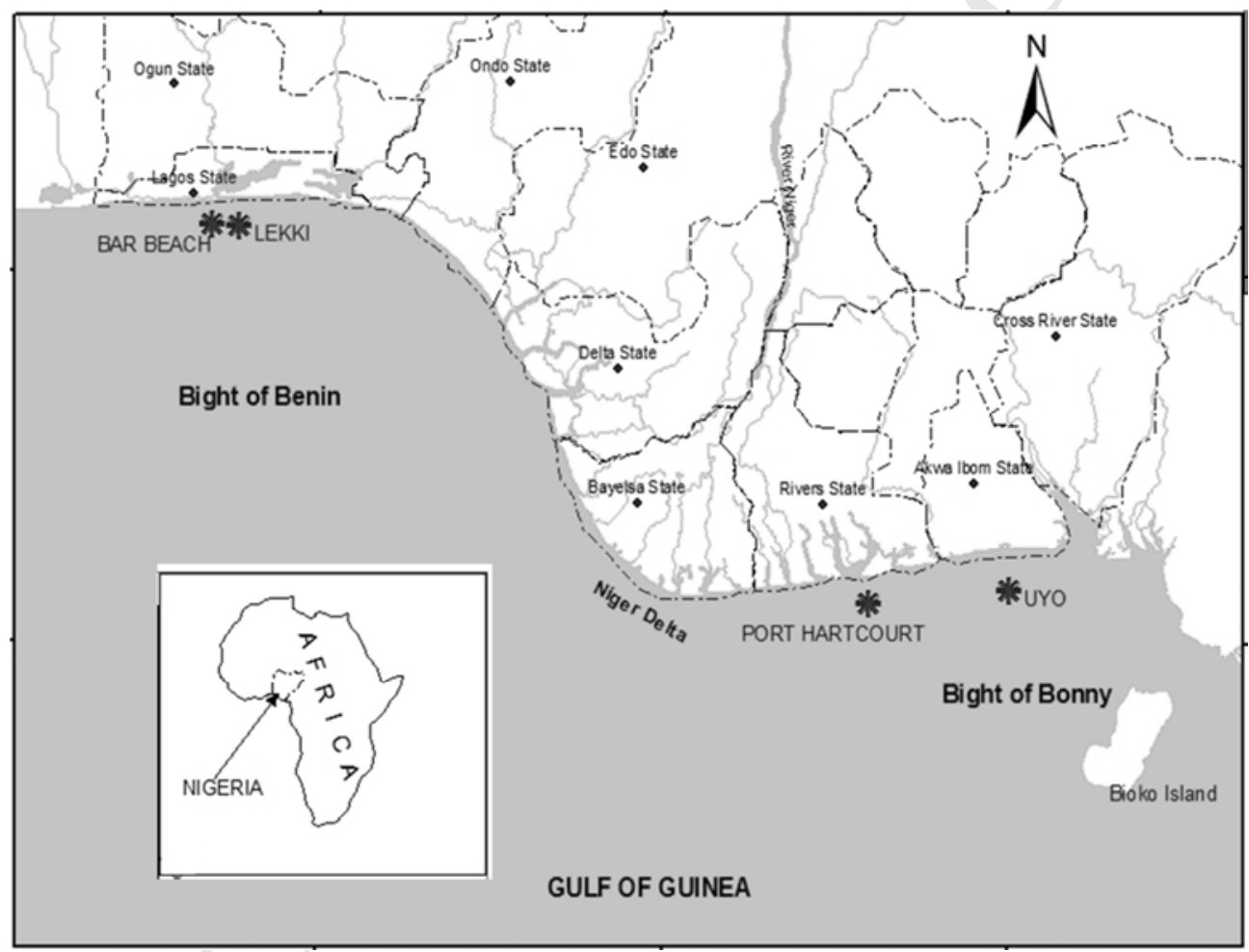

Figure 1: Location of sampling sites (stars): Bar Beach and Lekki are both in Lagos State off Lagos lagoon; Port Harcourt is in Rivers State, in the vicinity of the Niger delta, and Uyo is in Akwa Ibom State towards the Eastern Limit of Nigerian waters.

2.3. Physico-chemical parameters and water sampling for analysis of nutrients and phytoplankton identification 
Water samples $(1 \mathrm{~L})$ were obtained for analysis of nutrients at an integrated depth of $10 \mathrm{~m}$ to the surface of the ocean, with a lund tube of $2.5 \mathrm{~cm}$ diameter. Temperature was measured with a mercuryin-glass thermometer. Dissolved oxygen was measured using a Milwaukee NW 600 probe and salinity was measured with a Hach ${ }^{\mathrm{TM}}$ Salinity/Conductivity probe probe (Hach Company, USA).

Nutrients were analysed according to ASTM (1980). For the determination of nitrate, brucine sulphanilic acid reagent $(1 \mathrm{~mL})$ was added to standard solutions as well as to samples $(10 \mathrm{~mL})$. The resultant mixtures were mixed thoroughly and allowed to stand for $15 \mathrm{~min}$. Then $10 \mathrm{~mL}$ of $\mathrm{H}_{2} \mathrm{SO}_{4}$ solution were carefully added to $10 \mathrm{~mL}$ of distilled water and the resulting solution was added to each of the beakers containing the nitrate standard solutions and the water samples, respectively. This was allowed to stand for $20 \mathrm{~min}$ in the dark. Similar treatment was performed on the blank solution, using the same protocol except that no brucine sulphanilic reagent was added to it. The absorbance of standards and samples was determined at $410 \mathrm{~nm}$ wavelength using a UV/Visible spectrophotometer. Phosphate was determined using the ascorbic acid method. The programmed method of Hach was used using the Hach spectrophotometer DR2000 ${ }^{\mathrm{TM}}$ (Hach Company, USA).

Phytoplankton samples were collected by horizontal and vertical tows using a plankton net made from fine bolting silk ( $10 \mu \mathrm{m}$ mesh, length: $107 \mathrm{~cm}$ and Diameter: $29 \mathrm{~cm}$ ). Samples were drained into the plankton bucket and preserved with Lugol's iodine in sample bottles. Light microscopy (LM) observations were carried out from $50 \mu \mathrm{L}$ of fixed net samples deposited on a glass slide, using an Olympus IX70 inverted light microscope equipped with a digital camera DP72 (Olympus, Tokyo, Japan). Cells were photographed, either directly or after isolation with a micropipette, depending on concentration of organisms and particles.

\subsection{Passive sampler design, handling and extraction}

Passive sampling devices (Solid Phase Adsorption Toxin Tracking $=$ SPATT) were prepared using a $68 \mathrm{~mm}$ embroidery frame (Singer, Nantes, France). Three grams (3 g) of Diaion ${ }^{\circledR}$ HP-20 polymericresin were placed between two layers of a $30 \mu \mathrm{m}$ nylon mesh (Mougel, France), and clamped in the embroidery frame to form a thin layer of resin. To activate the HP-20 resin, the passive samplers were soaked for $3 \mathrm{~h}$ in methanol, rinsed twice with deionized water to remove methanol residues (Rundberget et al., 2009; Zendong et al., 2014) and directly deployed. Three SPATTs were put in three separate compartments cylinders made of steel, to firmly secure them, and deployed in the sea at $1 \mathrm{~m}$ depth for 7 days at each site. After deployment, the SPATTs were retrieved, rinsed with seawater to remove residual biofilm and transported in frozen ice packs to the laboratory. The SPATTs were shipped to the analytical laboratory in France on ice and arrived in good condition. They were then stored in a freezer $\left(-20^{\circ} \mathrm{C}\right)$ until analysis. The HP-20 resin was extracted according to previously 
published methods, with slight changes (Fux et al., 2008; Zendong et al., 2014). Briefly, after deployment, the SPATTs were rinsed twice in $500 \mathrm{~mL}$ deionized water, transferred into empty polypropylene reservoirs placed on a manifold and eluted dropwise with $24 \mathrm{ml}$ of methanol. The extracts were then evaporated at $45{ }^{\circ} \mathrm{C}$ under a gentle nitrogen stream. The dry residue was further reconstituted in $500 \mu \mathrm{L}$ of $50 \%$ methanol, filtered on Nanosep MF centrifugal filters $0.2 \mu \mathrm{M}$ (Pall) and transferred into HPLC vials for analysis.

\subsection{Liquid chromatography - mass spectrometry analyses}

Three different analytical systems were used: (1) for quantitative targeted analysis of toxins; (2) for untargeted screening of unknowns as well as known toxins; (3) for characterisation and confirmation of toxins. For all three systems, chromatographic separation was achieved after injection of a $3 \mu \mathrm{L}$ sample volume onto a Phenomenex Kinetex XB-C18 $(100 \times 2.6 \mathrm{~mm} ; 2.6 \mu \mathrm{m})$ column maintained at $40{ }^{\circ} \mathrm{C}$, with a flow rate of $400 \mu \mathrm{l} / \mathrm{min}$. The binary mobile phase consisted of water (A) and $95 \%$ acetonitrile/water (B), both containing $2 \mathrm{mM}$ ammonium formate and $50 \mathrm{mM}$ formic acid. The elution gradient rose from 5\% to $50 \%$ of B in $3.6 \mathrm{~min}$, then $100 \%$ B was reached by $8.5 \mathrm{~min}$. After $1.5 \mathrm{~min}$ of hold time at $100 \% \mathrm{~B}, 5 \% \mathrm{~B}$ was reached within $10 \mathrm{~s}$, followed by 5 min re-equilibration of the column at $5 \%$ B. The total chromatographic run time was $15 \mathrm{~min}$. To avoid cross contamination of samples, the needle was washed for $10 \mathrm{~s}$ in the flush port with $90 \% \mathrm{MeOH}$ before each injection. On all analytical systems, mass spectrometric acquisitions were carried out separately in positive $\left(\mathrm{ESI}^{+}\right)$and negative $\left(\mathrm{ESI}^{-}\right)$ionization modes.

\subsubsection{System 1: LC-MS/MS for quantitative analysis}

A UFLC-XR Shimadzu liquid chromatography system (Champs-sur-Marne, France) was connected to a hybrid triple quadrupole/linear ion-trap mass spectrometer (API4000-Q-Trap ${ }^{\mathrm{TM}}$; AB Sciex) equipped with a TurboIonSprayTM ionization source. For quantitation, the mass spectrometer was operated in MRM mode, scanning two transitions for each toxin. Q1 and Q3 resolutions of the instrument were set at Unit (arbitrary terms). Data were acquired in MRM, in separate chromatographic runs, using positive $\left(\mathrm{ESI}^{+}\right)$and negative (ESI) ionization modes, respectively with a scan time of $1 \mathrm{~s}$. In $\mathrm{ESI}^{+}$, the following source parameters were used: curtain gas set at $30 \mathrm{psi}$, ion spray at $5500 \mathrm{~V}$, a turbogas temperature of $450^{\circ} \mathrm{C}$, gas 1 and 2 both set at $50 \mathrm{psi}$, and an entrance potential of $10 \mathrm{~V}^{\text {. In ESI}}{ }^{-}$, the curtain gas was set at $20 \mathrm{psi}$, the ion spray at $-4500 \mathrm{~V}$, the turbogas temperature at $550^{\circ} \mathrm{C}$, gas 1 and 2 at 40 and $50 \mathrm{psi}$, respectively, and finally the entrance potential at $-13 \mathrm{~V}$. MRM transitions used for each toxin are displayed in Table 2. Data acquisition was carried out with Analyst 1.6 Software (AB Sciex). 
Table 2: Multiple Reaction Monitoring (MRM) transitions used for quantitative analysis on System 1 (30 msec dwell in $\mathrm{ESI}^{+}$and 80 msec dwell in $\mathrm{ESI}^{-}$).

\begin{tabular}{lcccccc}
\hline \multicolumn{1}{c}{ Toxin } & DP & Q1 & $\begin{array}{c}\text { Q3 } \\
\text { quantifier }\end{array}$ & CE & $\begin{array}{c}\text { Q3 } \\
\text { qualifier }\end{array}$ & CE \\
\hline DA & 61 & 312.1 & 266.1 & 23 & 161.1 & 35 \\
GYM-A & 86 & 508.4 & 490.2 & 33 & 392.3 & 49 \\
13-desmeSPX-C & 121 & 692.5 & 164.2 & 69 & 444.3 & 53 \\
PnTX-G & 141 & 694.5 & 164.1 & 75 & 458.3 & 75 \\
AZA1 & 116 & 842.5 & 672.4 & 69 & 654.4 & 69 \\
AZA2 & 116 & 856.5 & 672.4 & 69 & 654.4 & 69 \\
AZA3 & 116 & 828.5 & 658.4 & 69 & 640.4 & 69 \\
PTX2 & 91 & 876.5 & 823.5 & 31 & 805.6 & 37 \\
PTX2sa & 91 & 894.6 & 823.5 & 31 & 805.6 & 37 \\
OA, DTX2 & -170 & 803.5 & 255.1 & -62 & 113.1 & -92 \\
DTX1 & -170 & 817.5 & 254.9 & -68 & 112.9 & -92 \\
YTX & -120 & 1141.4 & 1061.6 & -48 & 855.5 & -98 \\
homo-YTX & -120 & 1155.6 & 1075.6 & -48 & 869.4 & -98 \\
\hline
\end{tabular}

\subsubsection{System 2: LC-HRMS for untargeted and targeted screening of toxins and unknowns}

A UHPLC system (1290 Infinity, Agilent Technologies) was coupled to a 6540 UHD Accurate-Mass QToF (Agilent Technologies) equipped with a dual ESI source. Full-scan analyses were performed over the range $\mathrm{m} / \mathrm{z} 65$ to 1700 with an acquisition rate of 2 spectra $\mathrm{s}^{-1}$. In $\mathrm{ESI}^{+}$the temperature of the Jet Stream Technologies ${ }^{\mathrm{TM}}$ source was set at $205^{\circ} \mathrm{C}$ with the drying gas flow-rate at $5 \mathrm{~L} \mathrm{~min}^{-1}$. The sheath gas temperature was $355^{\circ} \mathrm{C}$. Other parameters were as follows: capillary voltage, $2000 \mathrm{~V}$; fragmentor voltage, $200 \mathrm{~V}$. The parameters of the Jet Stream Technologies ${ }^{\mathrm{TM}}$ source in $\mathrm{ESI}^{-}$were: gas temperature $305^{\circ} \mathrm{C}$, drying gas flow $5 \mathrm{~L} \mathrm{~min}^{-1}$, nebulizer pressure $50 \mathrm{psi}$, sheath gas temperature 355 ${ }^{\circ} \mathrm{C}$, sheath $12 \mathrm{~L} / \mathrm{min}$, capillary voltage $3500 \mathrm{~V}$, fragmentor voltage, $180 \mathrm{~V}$.

All experiments were done with reference mass correction using purine $\left(\mathrm{m} / \mathrm{z} 121.0509[\mathrm{M}+\mathrm{H}]^{+} ; \mathrm{m} / \mathrm{z}\right.$ $119.03632[\mathrm{M}-\mathrm{H}]$ ] $)$ and HP-921 = hexakis $(1 \mathrm{H}, 1 \mathrm{H}, 3 \mathrm{H}$-tetrafluoropropoxy) phosphazine $(\mathrm{m} / \mathrm{z} 922.0099$ $\left.[\mathrm{M}+\mathrm{H}]^{+} ; \mathrm{m} / z 966.00072[\mathrm{M}+\mathrm{HCOO}]^{-}\right)$. The reference ions were infused constantly with an isocratic pump to a separate ESI sprayer in the dual spray source.

\subsubsection{System 3: LC-HRMS for toxins confirmation}

Analyses were carried out using a UHPLC system (1290 Infinity II, Agilent Technologies) coupled to a 6550 iFunnel QToF (Agilent Technologies) equipped with a dual ESI source. This instrument was operated with a dual electrospray ion source with Agilent Jet Stream Technology ${ }^{\mathrm{TM}}$ in positive and 
negative ionization modes. Analyses were performed over the range $\mathrm{m} / \mathrm{z} 100$ to 1200 with an acquisition rate of 2 spectra s ${ }^{-1}$. The parameters of the Jet Stream Technologies ${ }^{\mathrm{TM}}$ source in $\mathrm{ESI}^{+}$were: gas temperature $205^{\circ} \mathrm{C}$, drying gas flow $16 \mathrm{~L} / \mathrm{min}$, nebulizer pressure $50 \mathrm{psi}$, sheath gas temperature $355^{\circ} \mathrm{C}$, sheath $12 \mathrm{~L} / \mathrm{min}$, capillary voltage $2000 \mathrm{~V}$, fragmentor voltage, $200 \mathrm{~V}$. In ESI the parameters were as follows: gas temperature $290^{\circ} \mathrm{C}$, drying gas flow $12 \mathrm{~L} / \mathrm{min}$, nebulizer pressure 50 psi, sheath gas temperature $355^{\circ} \mathrm{C}$, sheath $12 \mathrm{~L} / \mathrm{min}$, capillary voltage $3500 \mathrm{~V}$, fragmentor voltage, $180 \mathrm{~V}$. Three collision energies $(20,40$ and $60 \mathrm{eV})$ were applied to the precursor ions to generate fragmentation spectrum. All experiments were done with reference mass correction as described above for System 2. MassHunter Acquisition B05.01 software was used to control the instrument and data were processed with MassHunter B07.00 service pack.

\subsection{Data processing and statistical analyses}

Raw data files obtained on System 2 (section 2.5.2) were processed using the Agilent Molecular Feature Extractor (MFE) algorithm in MassHunter Qual software (B.07). This algorithm was used to obtain the Total Compound Chromatogram of samples as previously described (Zendong et al., 2015). This algorithm designed for use with full scan data treats the mass spectral data as a three-dimensional array of retention time, $\mathrm{m} / \mathrm{z}$ and abundance values. Any point corresponding to persistent or slowlychanging background is removed from that array of values. Then the algorithm searches for ion traces that elute at very nearly the same retention times. Those ion traces are then grouped into entities called Compounds regrouping all ion traces that are related, i.e. those that correspond to mass peaks in the same isotope cluster, or can be explained as being different adducts or charge states of the same entity. The results for each detected Compound are a mass spectrum containing the ions with the same elution time and explainable relationships, and an extracted compound chromatogram (ECC) computed using all of these related ion traces in the compound spectrum (and only those traces). The results from the MFE analysis were then uploaded to the Agilent Mass Profiler Professional (MPP) software (B.13.00) as compound exchange format file (.cef) for further statistical analyses (PCA: Principal Component Analysis). In MPP, feature profiles were aligned with $15 \mathrm{ppm}$ and $0.2 \mathrm{~min}$ bins of mass and retention time windows, respectively. Data were $\log 2$ transformed, centered and normalized to give features equal weight in classification. Groups/conditions were composed of SPATT samples from the same location and/or the same deployment date. Data were analyzed by univariate and multivariate analysis to detect features of interest. For the multivariate data analysis (MVDA) comparing all samples, all features present in less than $20 \%$ of all samples from the data set were discarded. For univariate data analysis comparing only samples from a given site, only entities with p-values $>0.05$ and fold-change $>2$ were retained. PCA was carried out on conditions i.e. to allow for the detection of similarities between samples. Features that were considered characteristic were tentatively identified based on 
mass and spectral accuracy using the Dictionary of Marine Natural Products (DMNP) library (Blunt and Munro, 2008) (Wolfender et al., 2015).

\section{RESULTS AND DISCUSSION}

\subsection{Physico-chemical measurements}

Water temperatures, salinity and nutrient levels in the study area confirm a strong correlation with seasonality (Table 3). Salinity ranged from 2 to 20, all areas and periods confounded, which is comparatively low for marine dinoflagellates. The two stations in the North-west of the study area (Lekki and Bar Beach) displayed the highest salinities, ranging from 17.2 to 18.2 during the end of the wet season (October 2014), and from 18.1 to 19.3 during the dry season (January / February 2015). The stations closer to the Niger delta (off the cities of Port Harcourt and Uyo) showed much lower salinities, with the Port Harcourt station (directly outside the main delta in River States) showing the lowest overall salinity of 2 in wet season (October 2014) but still reaching a salinity of 9 during dry season (February 2015).

Table 3: Surface water temperature, dissolved oxygen (DO), salinity and nutrient concentrations at sampling stations in Nigerian coastal waters 2014-15.

\begin{tabular}{lcccccccc}
\hline Parameter & \multicolumn{2}{c}{ Bar Beach } & \multicolumn{2}{c}{ Lekki } & \multicolumn{2}{c}{ Port Harcourt } & \multicolumn{2}{c}{ Uyo } \\
\hline & $18 / 10 / 14$ & $02 / 02 / 15$ & $17 / 10 / 14$ & $30 / 01 / 15$ & $19 / 10 / 14$ & $04 / 02 / 15$ & $18 / 10 / 14$ & $03 / 02 / 15$ \\
\hline Water Temp $\left({ }^{\circ} \mathbf{C}\right)$ & 26 & 27 & 27 & 26 & 32 & 30 & 25.5 & 31 \\
DO $(\mathbf{m g} / \mathbf{L})$ & 7.8 & 9.8 & 7.8 & 7.9 & 7.8 & 6.5 & 7.4 & 6.5 \\
Salinity & 18.2 & 19.3 & 17.2 & 18.1 & 2.0 & 8.8 & 6.6 & 7.8 \\
$\mathbf{P O}_{\mathbf{4}}{ }^{-3}(\mathbf{m g} / \mathbf{L})$ & 0.07 & 0.51 & 0.03 & 0.2 & 0.07 & 0.22 & 0.03 & 0.51 \\
$\mathbf{N O}^{-}{ }^{-}(\mathbf{m g} / \mathbf{L})$ & 1.48 & 1.61 & 1.44 & 1.59 & 0.37 & 1.26 & 1.48 & 1.61 \\
\hline
\end{tabular}

\subsection{Identification of phytoplankton species}

Phytoplankton samples were generally dominated by diatoms and cyanobacteria, especially filamentous cyanobacteria. However, several species of marine dinoflagellates were also observed (Figure 2). In particular, a few cells of Dinophysis caudata were observed in a sample from Bar Beach (21 February 2015). D. caudata had previously been reported as a producer of OA and PTX2 in different areas and should thus be considered as a potentially toxic species (Fernández et al., 2006; Holmes et al., 1999; Li et al., 2015; Marasigan et al., 2001). Interestingly, different regions reported 
different profiles of toxins in picked cells of D. caudata. In Northwestern Spain and China, the toxin profile was dominated by PTX2 (Fernández et al., 2006; Li et al., 2015), while OA was shown to be present in picked cells of D. caudata from both Japanese and Singapore waters (Holmes et al., 1999; Marasigan et al., 2001).

Another potentially toxic dinoflagellate was observed in the sample from Bar Beach: Lingulodinium polyedrum. This species is characterized by its polyhedral shape with a flat antapex lacking any projections, thick thecal plates with ridges along the sutures and circular depressions over the surface of the plates (Dodge, 1989), see also Figure S2 (supplementary information). The same organism had also been detected at a concentration of several thousand cells $\mathrm{L}^{-1}$ in coastal waters of Atlantic Morocco (Bennouna et al., 2002), and cultures of Spanish strains of L. polyedrum were shown to produce yessotoxin (Paz et al., 2004).

Three cells of two unidentified benthic Prorocentrum species have also been observed (Figure 2c and d). A number of benthic Prorocentrum species have been associated with the production of toxins of the okadaic acid, the prorocentrolide and the hoffmaniolide groups: P. lima, P. belizeanum, $P$. maculosum, $P$. rhathymum and $P$. hoffmanianum (An et al., 2010; Hu et al., 1996; Jackson et al., 1993; Morton et al., 1998), but even a pelagic species of Prorocentrum (P. texanum) has recently been associated with the production of okadaic acid (Henrichs et al., 2013). Therefore, this observation should be verified to determine the exact species of Prorocentrum. 


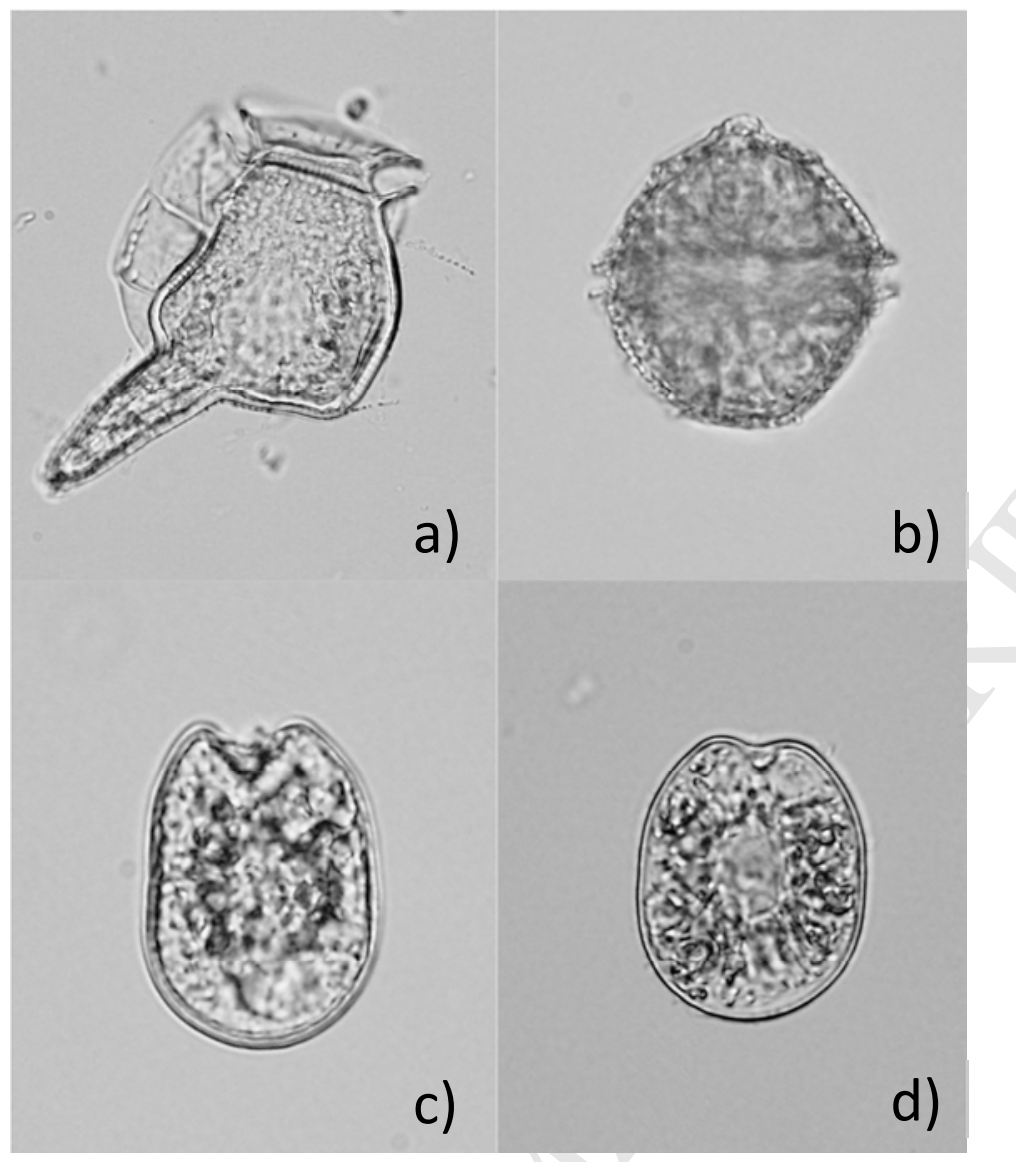

Figure 2: Marine dinoflagellates identified on Bar Beach (Lagos State, Nigeria, 21 February 2015): a) Dinophysis caudata $(\mathrm{L}=100 \mu \mathrm{m})$, b) Lingulodinium polyedrum $(\mathrm{L} \times \mathrm{W}: 40 \times 38 \mu \mathrm{m})$, c)

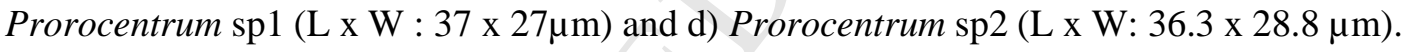

\subsection{Quantitative analysis of SPATT samples and toxin confirmation}

Passive samplers were deployed on different dates in November 2014 and February 2015. Analyses of SPATT carried out on System 1 revealed the presence of OA and PTX2 at different concentrations (Figure 3a). Concentrations of OA and PTX2 were significantly higher at Lekki and Bar Beach compared to Port Harcourt and Uyo. This overall pattern seems consistent with the higher potential for Dinophysis to survive in areas of higher salinity (Delmas et al., 1992). Dinophysis caudata had also been previously found at Bar Beach and Lekki, sites which at that time had almost oceanic salinity (Ajuzie and Houvenaghel, 2009). As abovementioned, D. caudata had previously been associated with the production of OA and PTX2, and hence the occurrence of these toxins in Nigerian waters can most likely be attributed to this species. The levels of okadaic acid found (ca. $60 \mathrm{ng} \mathrm{OA} \mathrm{g}{ }^{-1} \mathrm{HP}-20$ resin) were of a similar order of magnitude than those found by MacKenzie et al. (2004) in the initial study introducing passive sampling for algal toxins, but comparatively low compared to those reported in a previous study in Ireland (Fux et al., 2009). However, the concentrations in mussels (M. edulis) in the 
latter study also exceeded the regulatory level ca. 6-fold, and hence the actual contamination levels in shellfish in Nigeria should be verified to evaluate the risk for public health or before establishing commercial aquaculture sites. Interestingly, the levels of PTX2 observed in the present study were similar to those observed in the Irish study (Fux et al., 2009), which may be attributed to the different causative species in both areas: D. acuminata and D. acuta in Ireland, as compared to D. caudata in Nigeria. Rundberget et al. (2009) had used passive samplers of the same geometry in Norway, and they also found levels of a similar height of order as those in the present study. They also established that SPATTs contained typically three times as much toxin as mussels in a given location, yet occasionally levels in mussels were higher than those in the passive samplers. Since the Irish study did not have the same ratios as those established in the Norwegian study, we anticipate that any correlation between the concentrations observed in passive samplers and a given shellfish species would have to be established locally and verified over time.

The ratio of OA to PTX2 was examined to look for major changes in phytoplankton community structure of OA-producing organisms (Figure 3b). As Prorocentrum species have not been found to produce PTX2 but DTX1, a relative increase of OA over PTX2 could be indicative of their increasing importance. The ratio remained relatively constant over the study period indicating that there was either not much change in the population of micro-algae or similar ratios were produced by the organisms present. This is also consistent with the fact that DTX1 was found only in trace amounts at Lekki and Bar Beach, but not found at all in the two other locations. DTX1 has been reported from $P$. lima (Pan et al., 1999) and the low concentrations in passive samplers deployed at $1 \mathrm{~m}$ below the surface could be related to the dilution effect for these toxins if they had been produced by low density benthic species. However, it has been shown that even toxins from P. lima can accumulate to significant levels in shellfish locally (Lawrence et al., 2000), and hence care should be taken before discarding benthic organisms as a risk to public health.

At Bar Beach, it appeared that toxin concentrations were higher in November and in February which also coincides with a slight increase in salinity and the dry season, for which upwelling had been previously indicated (Ibe and Ajayi, 1985). At Port Harcourt and Uyo, concentrations of OA and PTX2 in the passive samplers were $c a$. 10-fold lower than the maxima observed at Bar Beach and Lekki. This significant difference is understandable from the very low salinities observed at Port Harcourt and Uyo (Table 3), which are detrimental for most marine dinoflagellates, in particular Dinophysis (Delmas et al., 1992). The differences in concentrations found in passive samplers extracts from Port Harcourt and Uyo on one hand and Lekki and Bar Beach on the other are much larger than what could be expected from the simple differences in adsorption due to different salinities. A recent study has shown that kinetics of adsorption may be affected (Fan et al., 2014), however, this should be negligible for the 1-week deployment periods in the present study. Port Harcourt and Uyo are 
considered to be brackish water zones and are consequently significantly different from Bar Beach and Lekki (see also section on untargeted analysis).

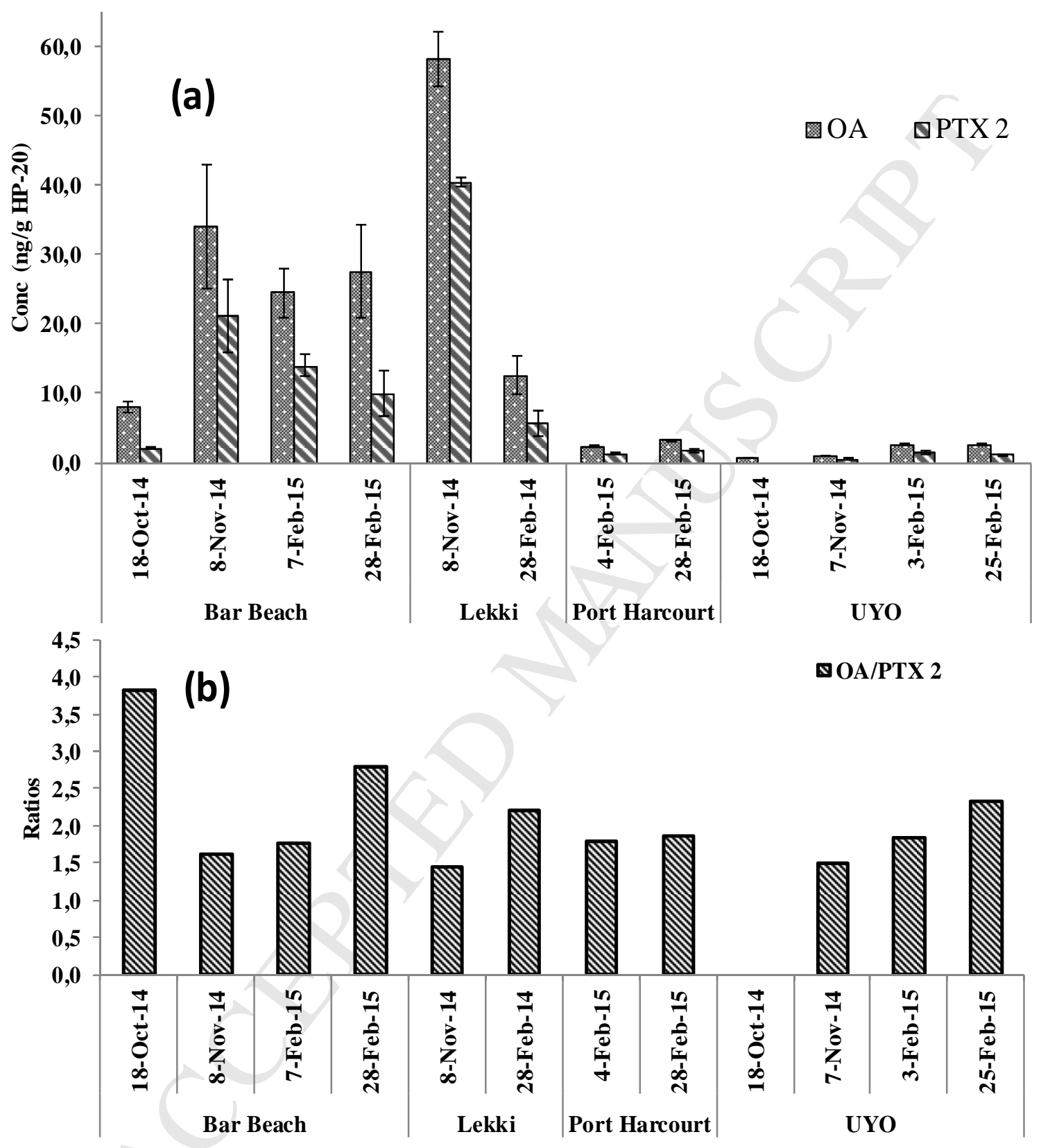

Figure 3: Average concentrations (a) and ratios (b) of okadaic acid (OA) and pectenotoxin 2 (PTX2) detected at each deployment site (ng/g of HP-20 resin \pm RSD $\%, n=3$ ).

3.4. Confirmation of okadaic acid and pectenotoxin 2 by high resolution mass spectrometry coupled to liquid chromatography 
For confirmatory purposes, System 3 was used to obtain high resolution spectra from toxins quantified using System 1. For instance, the spectra for OA in negative ionisation mode obtained from a standard solution and a sample from Bar Beach were compared, and showed the same major ions characteristic for OA (Figure 4).

Accurate mass measurements for OA for the sample from Bar Beach were also verified and compared well with those of the certified standard of OA: the molecular ion $[\mathrm{M}-\mathrm{H}]^{-}$of $\mathrm{OA}$ in the Bar Beach sample ( $\mathrm{m} / \mathrm{z}$ 803) showed $1.2 \mathrm{ppm}$ mass error compared to the standard, while the two main fragments $\mathrm{m} / \mathrm{z} 113.060$ and 255.123 had a mass error of 0.88 and $0.39 \mathrm{ppm}$, respectively. Mass accuracy for PTX2 was slightly less good, but fragmentation pattern and fragment ion ratios matched very well that of the standard (see Figure S1, supplementary information). Therefore, the presence of OA and PTX2 can be considered unequivocal as demonstrated by both low and high resolution tandem mass spectrometry.
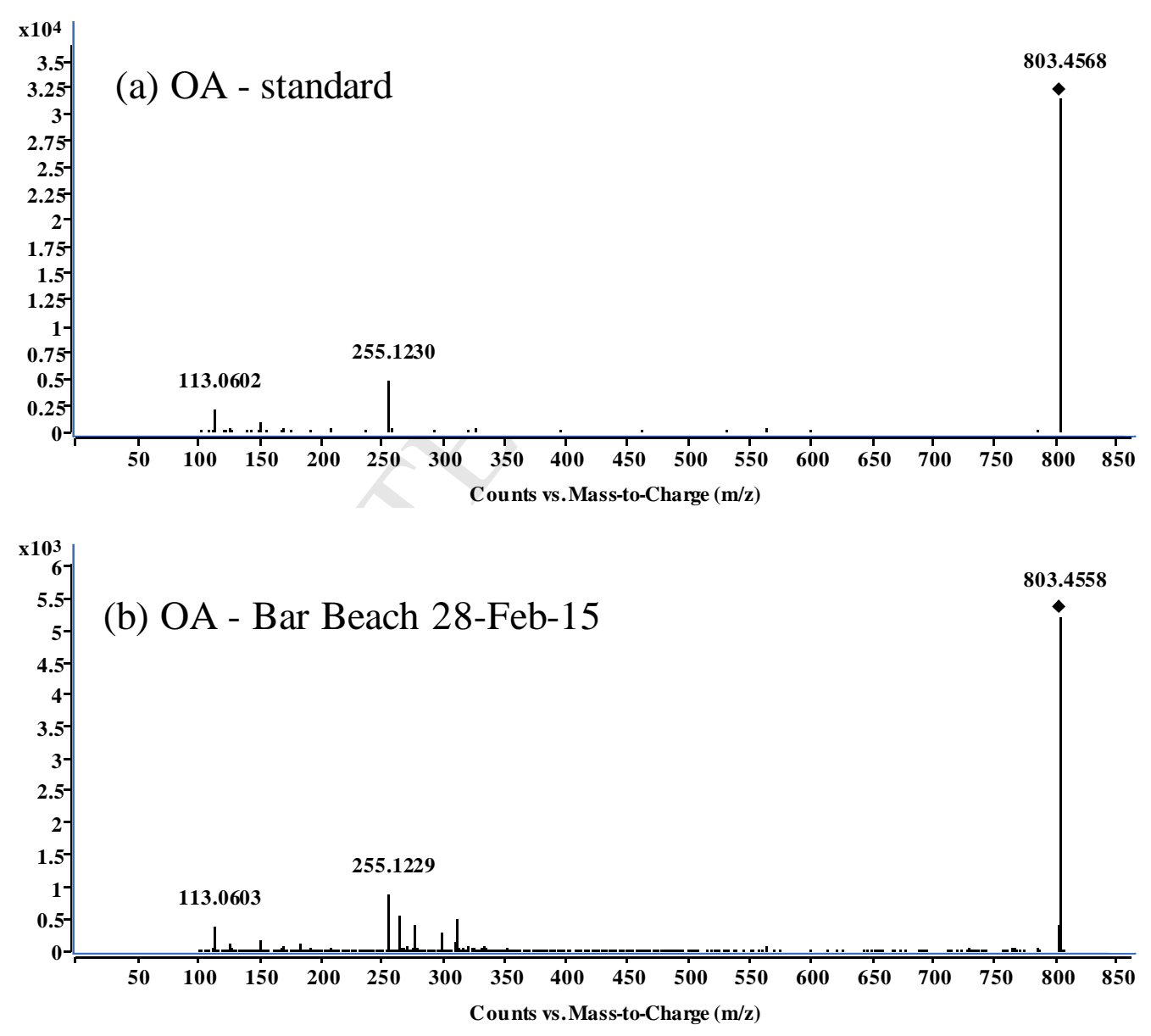

Figure 4: Average high resolution spectrum of (a) OA standard and (b) OA in a SPATT extract from Bar Beach. Spectra were obtained on System 3 (QToF 6550) in ESI- using target MS/MS with collision energies of $20 \mathrm{~V}, 40 \mathrm{~V}$ and $60 \mathrm{eV}$. 


\subsection{Untargeted screening approach for passive samplers}

Principal component analysis including all masses identified in extracts of the passive samplers clearly showed separation between samples taken at the end of the wet season and those taken during the dry season, irrespective of the sampling site (Figure 5).

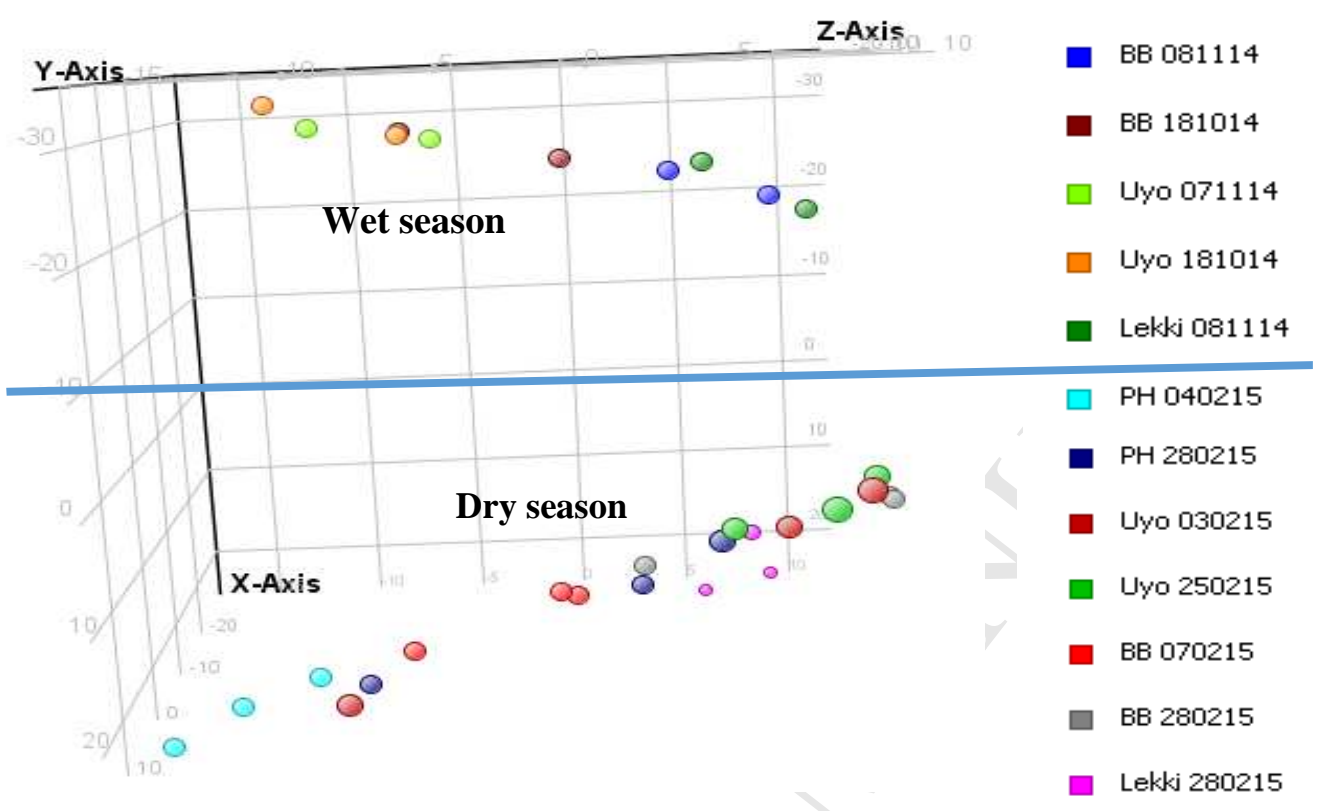

Figure 5: Score plot of the principal component analysis of all passive samplers ( $\mathrm{n}=2$ for 2014 and $\mathrm{n}=3$ for 2015). Data were acquired by full scan HRMS on System 2. During Molecular Feature Extraction samples were blank-subtracted, ion traces extracted and combined into compounds. The three principal components plotted on the $\mathrm{X}, \mathrm{Y}$, and $\mathrm{Z}$ axes account for ca. $58 \%$ of the total variability in the data set $(40.94 \%$ for $\mathrm{X} ; 11.18 \%$ for $\mathrm{Y}$ and $7.06 \%$ for Z). Note: $\mathrm{BB}=\mathrm{Bar}$ Beach and $\mathrm{PH}=$ Port Harcourt.

This separation of seasons in the passive sampler extracts was not as distinct as in the targeted analysis of toxins (Figure 3a) but is consistent with changes expected in the phytoplankton community structures in different seasons. When analysing the trend on a single site, Bar Beach (BB), it was also apparent that each sampling occasion gave a different chemical profile (Figure 6). 


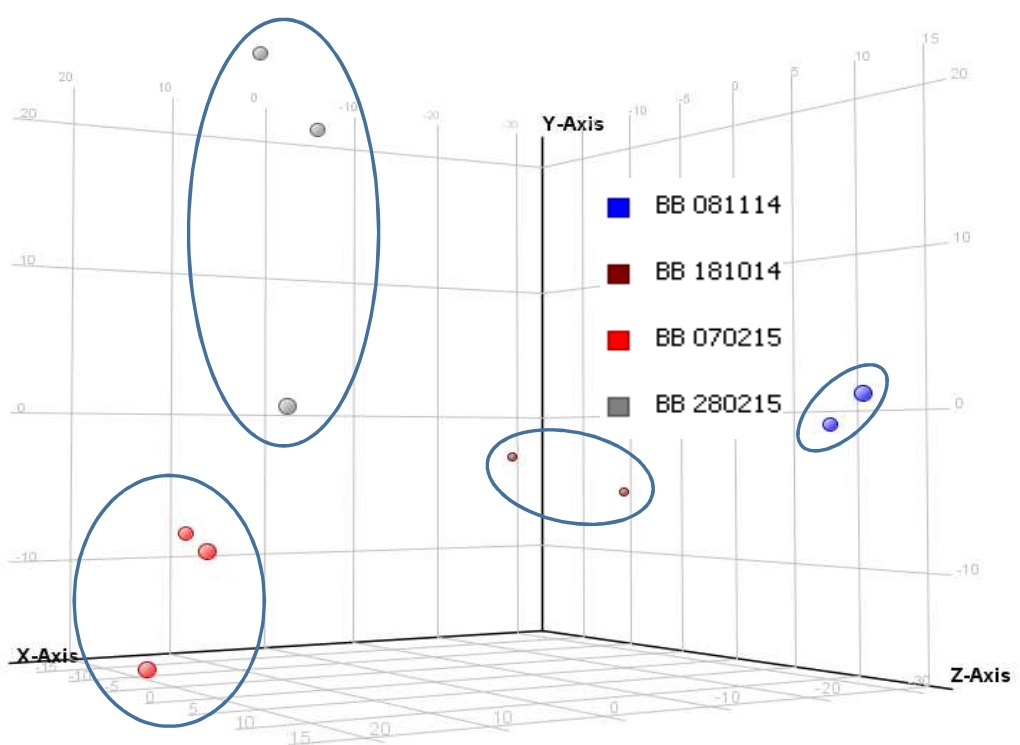

Figure 6: Score plot of the principal component analysis of passive samplers from Bar Beach taken on four separate occasions ( $\mathrm{n}=2$ for 2014 and $\mathrm{n}=3$ for 2015). Data were acquired by full scan HRMS on system 2. The three principal components plotted on the $\mathrm{X}, \mathrm{Y}$, and $\mathrm{Z}$ axes account for ca. $83 \%$ of the total variability in the data set $(69.72 \%$ for $\mathrm{X} ; 7.78 \%$ for $\mathrm{Y}$ and $5.78 \%$ for $\mathrm{Z})$

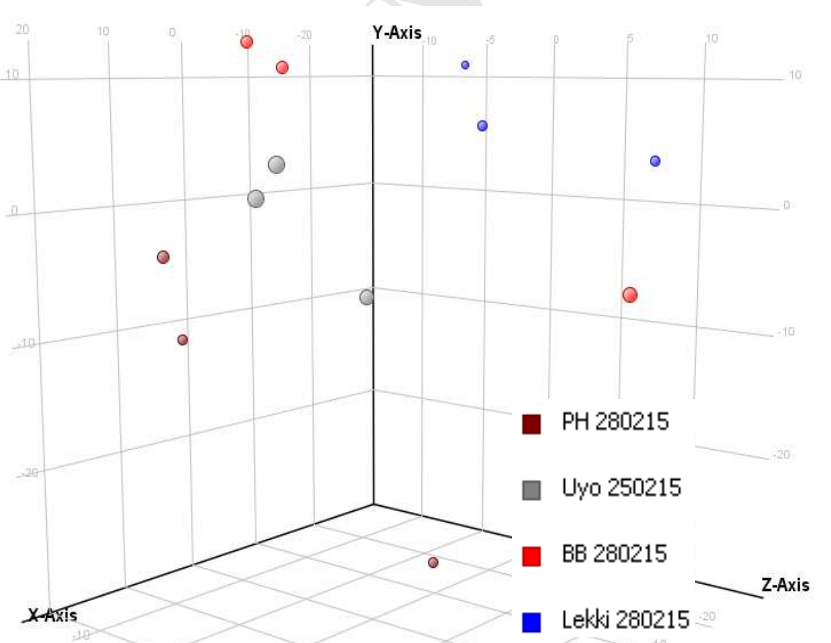

Figure 7: Score plot of the principal component analysis of passive samples from all four sites (BB=Bar Beach, $\mathrm{PH}=$ Port Harcourt), all taken during week 9 of 2015 ( $\mathrm{n}=3)$. The three principal components plotted on the $\mathrm{X}, \mathrm{Y}$, and $\mathrm{Z}$ axes account for ca. $66 \%$ of the total variability in the data set (39.04\% for $\mathrm{X} ; 18.79 \%$ for $\mathrm{Y}$ and $9.04 \%$ for $\mathrm{Z}$ ). 
Interestingly, all four sites gave also different chemical profiles on a single sampling occasion (Figure 7). In this initial untargeted analysis, no identification of compounds was necessary to obtain this trend.

Still, the separation of the sites by PCA is not surprising when considering that the complete set of data for these four sites on a single occasion consisted of 2394 compounds. Amongst those compounds, 1828 occurred only at the two sites of high salinity (Lekki and Bar Beach) and 245 were unique to the sites with low salinity (Uyo and Port Harcourt). This also means that only 321 compounds were common to all four sites during that particular week. This observation also led us to tentatively identify what compounds may occur on the different sites. For this purpose, several samples were also screened against a database derived from the Dictionary of Marine Natural Products (Blunt and Munro, 2008). When applying stringent criteria (1 ppm mass accuracy, 5000 count abundance threshold) for matching compounds identified in the Nigerian data set by full scan HRMS, several hundred compounds gave tentative hits.

In particular, we examined what compounds were responsible for distinguishing weeks at Bar Beach station. In the PCA analysis for Bar Beach samples from October/November 2014 were grossly separated from samples taken during February (Figure 6). When examining compounds with extreme loadings in the PCA analysis $(<-0.03$ or $>0.03$ normalised loading values, arbitrary choice, see Figure S3), 20 compounds of 196 distinctive entities were tentatively identified for the earlier period (October and November 2014, end of wet season), while 20 compounds of 424 distinctive entities were tentatively identified for the later period (February 2015, dry season, Table 4). In summary, among the database propositions were many compounds that had initially been identified either in tropical sponges, nudibranches or marine or freshwater cyanobacteria (Table 4). The fact that cyanobacterial compounds were identified appears coherent with previous identification of cyanobacteria as a problem in Nigerian waters (Odokuma and Isirima, 2007). These findings also suggest that additional efforts in Nigerian coastal waters should focus on identifying cyanobacterial toxins and source organisms.

Without any pre-selection of compounds on a given site for one sampling occasion (contrarily to the comparative PCA described above), many compounds can be tentatively identified, however, not all are distinctive features of that site - occasion combination. For instance Bar Beach was analysed for identifiable compounds on 08/11/2014 and 170 compounds gave a hit in the Dictionary of Marine Natural Products (Blunt and Munro, 2008). Interestingly, these compounds tentatively identified in the non-targeted analysis also included for instance okadaic acid already identified in the targeted analysis (Table S1). 
1 Table 4. Compounds tentatively identified in non-targeted analysis using high-resolution mass spectrometry (system 2)

\begin{tabular}{|c|c|c|c|c|c|c|}
\hline No. & Compound & Month & Freq. & $\mathbf{T}_{\mathbf{R}}$ & Mass & Identification Marine Natural Products Dictionary \\
\hline 1 & 6-Tridecylamine & Feb & 6 & 4.01 & 199.2296 & Isolated from the cyanobacterium Microcoleus lyngbyaceus \\
\hline 2 & Hedaol B; A5-Isomer(Z-) & $\mathrm{Feb}$ & 6 & 7.08 & 261.1977 & Constituent of a Sargassum sp. \\
\hline 3 & $\begin{array}{l}8,11,14 \text {-Heptadecatrienal; (all-Z) -form, } \\
\text { 14,15-Dihydro }\end{array}$ & Feb & 6 & 5.27 & 250.2293 & $\begin{array}{l}\text { Constituent of cucumber, tobacco and wheat. Also found in the } \\
\text { algae Enteromorpha sp., Scytosiphon lomentaria and Ulva pertusa }\end{array}$ \\
\hline 4 & $\begin{array}{l}\text { Glycerol 1-alkyl ethers; Glycerol 1- } \\
\text { pentadecyl ether }\end{array}$ & Feb & 6 & 8.61 & 302.2818 & Constituent of Desmapsamma anchorata and Tethya aurantiaca \\
\hline 5 & $\begin{array}{l}\text { 10-Aromadendranol; (1ct,4a,5 13,6a,7a,10a)- } \\
\text { form, O -(2-O - }\end{array}$ & Feb & 6 & 7.21 & 405.3120 & $\begin{array}{c}\text { Constituent of Eucalyptus globulus (Tasmanian blue gum) and } \\
\text { Thryptomene kochii }\end{array}$ \\
\hline 6 & Petroformyne $1 ; 3$ - or 44 - Ketone & Feb & 6 & 3.22 & 666.5018 & Constituent of Petrosia ficiformis \\
\hline 7 & $\begin{array}{l}\text { Dideacetylraspacionin; 10,28-Dihydro, } 103- \\
\text { hydroxy, 4,10, 15,21-tetra-Ac }\end{array}$ & Feb & 6 & 8.16 & 661.4090 & Constituent of sponge Raspaciona aculeata \\
\hline 8 & $\begin{array}{l}\text { Dideacetylraspacionin; 10,28-Dihydro, } 103 \text { - } \\
\text { hydroxy, } 21 \text { - ketone, 4,10,15-tri-Ac }\end{array}$ & Feb & 6 & 8.21 & 634.4068 & Constituent of sponge Raspaciona aculeata \\
\hline 9 & $\begin{array}{l}\text { Cholestane-3,5,6,7-tetrol; (3i, 5ct,613,713)- } \\
\text { form, 3,7-Di-Ac }\end{array}$ & $\mathrm{Feb}$ & & 8.25 & 503.3500 & Constituent of the gorgonian Plexaurella grisea \\
\hline 10 & 6-Pentadecyl-1,2,4-benzenetriol; 1 -Ac & Feb & 6 & 7.59 & 400.2594 & Constituent of the sponge Axinella polycapella \\
\hline 11 & Etzionin; N,O -Di-Ac & Feb & 6 & 7.41 & 558.3422 & cytotoxic \& antifungal; isolated from Didemnum rodriguesi \\
\hline 12 & Fumiquinazoline $\mathrm{F}$; 4-Epimer & Feb & 6 & 7.47 & 358.1420 & Cytotoxin prod. by a marine-derived Aspergillus fumigatus \\
\hline 13 & Picrotoxinin & Feb & 6 & 3.77 & 314.0767 & Ichthyotoxin isolated from desmosponge Spirastrella inconstans \\
\hline 14 & Louludinium $(1+)$ & Feb & 6 & 4.82 & 294.2211 & Isolated from marine cyanobacterium Lyngbya gracilis \\
\hline $15^{--}$ & Aeruginosamide & Feb & 6 & 2.66 & 560.3399 & Isolated from Microcystis aeruginosa (cyanobacteria) \\
\hline 16 & Bengamide Z; 6-Deoxy & Feb & 6 & 2.30 & 372.2264 & Isolated from sponge Jaspis cf. coriacea \\
\hline $17^{-}$ & Ulithiacyclamide $\mathrm{F}$ & $\mathrm{Feb}$ & 6 & 9.26 & 814.2046 & Isolated from the ascidian Lissoclinum patella \\
\hline
\end{tabular}




\begin{tabular}{|c|c|c|c|c|c|c|}
\hline No. & Compound & Month & Freq. & $\mathbf{T}_{\mathrm{R}}$ & Mass & Identification Marine Natural Products Dictionary \\
\hline 18 & 4-Cadinen-10-ol; (1ct,63,7i3,10 13)-form & $\mathrm{Feb}$ & 6 & 4.46 & 222.1987 & olated from the sponge Acanthella cavernosa. \\
\hline 19 & Drechslerine $\mathrm{G}$ & Feb & 6 & 3.85 & 270.1823 & Metabolite of the algicolous fungus Drechslera dematioidea \\
\hline 20 & Acremonin A; (+)-form & Feb & 6 & 5.25 & 176.0836 & Prod. by a marine-derived micromycte Acremonium sp. \\
\hline 21 & $\begin{array}{l}10-\mathrm{O}-(3,4-\text { Dihydroxy-E -cinnamoyl }) \\
\text { geniposidic acid }\end{array}$ & Oct/Nov & 4 & 2.87 & 536.1535 & $\begin{array}{l}\text { Constituent of Genipa americana (genipap) and Premna barbata } \\
\text { (higher terrestrial plants) }\end{array}$ \\
\hline 22 & $\begin{array}{l}\text { 6- Sulfate Cholestane-3,6,8,15,24-pentol; } \\
(313,5 \mathrm{ct}, 6 \mathrm{a}, 15 \mathrm{ct}, 24 \mathrm{~S}) \text {-form, }\end{array}$ & Oct/Nov & 4 & 2.1 & 532.3077 & Constituent of Oreaster reticulatus (tropical sea star) \\
\hline 23 & $\begin{array}{l}\text { 3-Propanoyl, 12-Ac-3,12-Dihydroxy-20,24- } \\
\text { dimethyl-17-scalaren-25,24-olide }\end{array}$ & Oct/Nov & 4 & 6.36 & 545.371 & Constituent of Phyllospongia lamellosa \\
\hline 24 & 1-Tricosene & Oct/Nov & 4 & 9.23 & 339.3865 & $\begin{array}{l}\text { Constituent of the alga Botryococcus braunii and various plant spp. } \\
\text { incl. Gardenia tahitensis }\end{array}$ \\
\hline 25 & 4,10-Dimethyldodecanoic acid & Oct/Nov & 4 & 3.85 & 245.2352 & Isolated from a halophilic Bacillus sp. \\
\hline 26 & 2-Amino-11-dodecen-3-ol & Oct/Nov & 3 & 5.50 & 199.1939 & Isolated from a marine sponge Haliclona n. sp. \\
\hline 27 & $\mathrm{~N}$ - Eicosanoyl 2-Aminobenzoic acid & Oct/Nov & 4 & 5.65 & 453.3218 & Isolated from aerial parts of Ononis natrix (African terrestrial plant) \\
\hline 28 & Dysidazirine; (S ,E )-form & Oct/Nov & 4 & 3.69 & 307.2516 & Isolated from Fijian marine sponge, Dysidea fragilis \\
\hline 29 & Malonganenone B & Oct/Nov & 4 & $6.75^{-}$ & 470.3256 & Isolated from Leptogorgia gilchristi (gorgonian, soft coral) \\
\hline 30 & Glanvillic acid A & Oct/Nov & 4 & 6.29 & 306.2190 & Isolated from Plakortis halichondrioides \\
\hline 31 & 13,14 -Dihydro-amphiasterin B2 & Oct/Nov & 3 & 6.72 & 401.3506 & Isolated from Plakortis quasiamphiaster (marine sponge) \\
\hline 32 & Enterocin & Oct/Nov & 4 & 3.75 & 444.1060 & Isolated from a marine ascidian Didemnum sp. \\
\hline 33 & Phloeodictyne A; Phloeodictyne 4,6i & Oct/Nov & 4 & 8.59 & 407.3622 & $\begin{array}{l}\text { Isolated from the New Caledonian deep water sponge Phloeodictyon } \\
\text { fistulosa) }\end{array}$ \\
\hline 34 & 2-Ámino-18-methyl-4- nonadecene-1,3-diol & Oct/Nov & 3 & 8.7 & 327.3141 & Isolated from the sponge Discodermia calyx \\
\hline 35 & $\begin{array}{l}\text { 2-Amino-9-hexadecen-3-ol; }(2 \mathrm{~S}, 3 \mathrm{R}, 9 \mathrm{Z}) \text { - } \\
\text { form }\end{array}$ & Oct/Nov & 4 & 7.87 & 255.2563 & Isolated from the tunicate Pseudodistoma obscurum \\
\hline
\end{tabular}




\begin{tabular}{clccccc}
\hline No. & Compound & Month & Freq. & $\mathbf{T}_{\mathbf{R}}$ & Mass & Identification Marine Natural Products Dictionary \\
\hline 36 & 6-Octadecenoic acid; (E)- form & Oct/Nov & 4 & 7.72 & 282.2559 & Minor constituent of plant oils \\
\hline 37 & Choline; O -(2-Methyl-2- propenoyl) & Oct/Nov & 4 & 8.08 & 194.1157 & Monomer. Polymers are used as coagulants in sewage treatment \\
\hline 38 & 2-Dodecenoic acid; (E)-form, Et ester & Oct/Nov & 4 & 7.12 & 226.1909 & \\
\hline 39 & Hexadecanoic acid; Dimethylamide & Oct/Nov & 4 & 5.74 & 283.2876 & Occurs in pears \\
\hline 40 & 2-Methylpropanoic acid & Oct/Nov & 4 & 7.69 & 106.0627 & The free acid and its esters occur in many plants \\
\hline
\end{tabular}

2 


\section{CONCLUSION}

The survey in Nigerian coastal waters confirmed the presence of toxic algae in this area, in particular Dinophysis caudata. For the first time, lipophilic toxins were identified in Nigerian coastal waters. Okadaic acid and pectenotoxin 2 have been quantified in passive samplers deployed for 1-week periods and can most likely be attributed to Dinophysis species, although a partial contribution by Prorocentrum species cannot be excluded. Untargeted analysis using high resolution mass spectrometry also pointed towards the possible accumulation of cyanobacterial metabolites in the passive samplers. Therefore, any further studies investigating the risks for public health from shellfish consumption should examine concentrations of algal as well as cyanobacterial toxins.

\section{CONFLICT OF INTEREST}

The authors declare that there are no conflicts of interest.

\section{AKNOWLEDGMENTS}

This study was carried out under the Coselmar project supported by Ifremer and Nantes University and funded by the Regional Council of the Pays de la Loire, France. The authors would like to thank all the members of the Laboratory Phycotoxins at the Atlantic Centre of Ifremer for their help and advice during this study. Tertiary Education Trust (TETF) is appreciated for providing logistics support for the collection of samples. Dr Denise Mukoro and Mr. Timothy Efe Unusiotame-Owolagba are gratefully acknowledged for the deployment of the SPATTs.

\section{REFERENCES}

Abouabdellah, R., Bennouna, A., El Attar, J., Erler, K., Dellal, M., Chafik, A., Moukrim, A., 2011. Diarrhetic shellfish poisoning toxin profile of shellfish from Southern Atlantic coasts of Morocco. South Asian Journal of Experimental Biology 1, 101-106.

Abouabdellah, R., Taleb, H., Bennouna, A., Erler, K., Chafik, A., Moukrim, A., 2008. Paralytic shellfish poisoning toxin profile of mussels Perna perna from southern Atlantic coasts of Morocco. Toxicon 51, 780-786.

Ajuzie, C., Houvenaghel, G., 2009. Preliminary survey of potentially harmful dinoflagellates in Nigeria's coastal waters. Fottea 9, 107-120. 
An, T., Winshell, J., Scorzetti, G., Fell, J.W., Rein, K.S., 2010. Identification of okadaic acid production in the marine dinoflagellate Prorocentrum rhathymum from Florida Bay. Toxicon 55, 653-657.

ASTM, 1980. American Society for Testing and Materials. Annual Book of ASTM Standard. pp. 547-549.

Bennouna, A., Berland, B., El Attar, J., Assobhei, O., 2002. Lingulodinium polyedrum (Stein) Dodge red tide in shellfish areas along Doukkala coast (Moroccan Atlantic). Oceanologica Acta 25, 159-170.

Bienfang, P., Oben, B., DeFelice, S., Moeller, P., Huncik, K., Oben, P., Toonen, R., Daly-Engel, T., Bowen, B., 2008. Ciguatera: the detection of neurotoxins in carnivorous reef fish from the coast of Cameroon, West Africa. Afr. J. Mar. Sci. 30, 533-540.

Blanco, J., Livramento, F., Rangel, I.M., 2010. Amnesic shellfish poisoning (ASP) toxins in plankton and molluscs from Luanda Bay, Angola. Toxicon 55, 541-546.

Blunt, J.W., Munro, M.H., 2008. Dictionary of Marine Natural Products, with CD-ROM. Chapman \& Hall, CRC Press, Taylor and Francis Group, Boca Raton, London, New York.

DeGrasse, S.L., Martinez-Diaz, K., 2012. Biotoxin control programmes in North, Central and South American countries, in: Cabado, A.G., Vieites, J.M. (Eds.), New Trends in Marine and Freshwater Toxins: Food Safety Concerns. Nova Science Publishers Inc.

Delmas, D., Herbland, A., Maestrini, S.Y., 1992. Environmental conditions which lead to increase in cell density of the toxic dinoflagellates Dinophysis spp in nutrient-rich and nutrient-poor waters of the French Atlantic coast Marine Ecology Progress Series 89, 53-61.

Dublin-Green, C.O., Awobanise, A., Ajao, E.A., 1997. Large Marine Ecosystem Project for the Gulf of Guinea (Coastal Profile of Nigeria). Nigeria Institute of Oceanography Encyclopedia Americana, 1994. International Edition, Grolier Incorporated

Fan, L., Sun, G., Qiu, J., Ma, Q., Hess, P., Li, A., 2014. Effect of seawater salinity on pore-size distribution on a poly(styrene)-based HP20 resin and its adsorption of diarrhetic shellfish toxins. Journal of Chromatography A 1373, 1-8.

Fawcett, A., Bernard, S., Pitcher, G.C., Probyn, T.A., du Randt, A., 2006. Real-time monitoring of harmful algal blooms in the southern Benguela. African Journal of Marine Science 28, 257-260.

Fernández, M.L., Reguera, B., González-Gil, S., Míguez, A., 2006. Pectenotoxin-2 in single-cell isolates of Dinophysis caudata and Dinophysis acuta from the Galician Rías (NW Spain). Toxicon 48, 477-490.

Fux, E., Bire, R., Hess, P., 2009. Comparative accumulation and composition of lipophilic marine biotoxins in passive samplers and in mussels (M. edulis) on the West Coast of Ireland. Harmful Algae 8, 523-537.

Fux, E., Marcaillou, C., Mondeguer, F., Bire, R., Hess, P., 2008. Field and mesocosm trials on passive sampling for the study of adsorption and desorption behaviour of lipophilic toxins with a focus on OA and DTX1. Harmful Algae 7, 574-583.

Henrichs, D.W., Scott, P.S., Steidinger, K.A., Errera, R.M., Abraham, A., Campbell, L., 2013. Morphology and Phylogeny of Prorocentrum texanum sp nov (Dinophyceae): A New Toxic Dinoflagellate From the Gulf of Mexico Coastal Waters Exhibiting Two Distinct Morphologies. J. Phycol. 49, 143-155. 
Hess, P., 2012. Phytoplankton and biotoxin monitoring programmes for the safe exploitation of shellfish in Europe, in: Cabado, A.G., Vieites, J.M. (Eds.), New Trends in Marine and Freshwater Toxins: Food Safety Concerns. Nova Science Publishers Inc.

Holmes, M.J., Teo, S.L.M., Lee, F.C., Khoo, H.W., 1999. Persistent low concentrations of diarrhetic shellfish toxins in green mussels perna viridis from the johor strait, singapore: first record of diarrhetic shellfish toxins from south-east asia. Marine-Ecology-Progress-Series 181, 257-268.

Hu, T., DeFreitas, A.S.W., Curtis, J.M., Oshima, Y., Walter, J.A., Wright, J.L.C., 1996. Isolation and structure of prorocentrolide B, a fast-acting toxin from Prorocentrum maculosum. J. Nat. Prod. 59, 10101014.

Ibe, A.C., 1988. The Niger Delta and the global rise in sea level. Proc. SCORE Workshop on sea level rise and subsidiary coastal areas. Milliman Press, New York.

Ibe, A.C., Ajayi, T.O., 1985. Possible Upwelling Phenomenon off the Nigerian Coast. NIOMR Technical Publication 25, 1-30.

Jackson, A.E., Marr, J.C., McLachlan, J.L., 1993. The production of diarrhetic shellfish toxins by an isolate of Prorocentrum lima from Nova Scotia, Canada. 513-518.

Kadiri, M.O., 1999. Phytoplankton distribution in the coastal waters of Nigeria. Nigerian Journal of Botany 12, 51-62.

Kadiri, M.O., 2001. Some marine phytoplankton species from Atlantic Ocean, Nigeria. Biosci. Res. Comm 13, 197-207.

Kadiri, M.O., 2002. A spectrum of phytoplankton flora along salinity gradient in the eastern Niger Delta area of Nigeria. Acta Botanica Hungarica 44, 75-83.

Kadiri, M.O., 2006a. Phytoplankton flora and physico-chemical attributes of some waters in the Eastern Niger delta area of Nigeria. Nigerian J. Botany 19, 188-200.

Kadiri, M.O., 2006b. Phytoplankton survey in the Western Niger Delta, Nigeria. Afr. J. Environ. Pollut. Health 5, 48-58.

Kadiri, M.O., 2011. Notes on harmful algae from Nigerian coastal waters. Acta Botanica Hungarica 53, 137-143.

Lawrence, J., Loreal, H., Toyofuku, H., Hess, P., Iddya, K., Ababouch, L., 2011. Assessment and management of biotoxin risks in bivalve molluscs. FAO Fisheries and Aquaculture Technical Paper No. 551,337 pages.

Lawrence, J.E., Grant, J., Quilliam, M.A., Bauder, A.G., Cembella, A.D., 2000. Colonization and growth of the toxic dinoflagellate Prorocentrum lima and associated fouling macroalgae on mussels in suspended culture. Mar. Ecol.-Prog. Ser. 201, 147-154.

Li, A.F., Sun, G., Qiu, J.B., Fan, L., 2015. Lipophilic shellfish toxins in Dinophysis caudata picked cells and in shellfish from the East China Sea. Environ. Sci. Pollut. Res. 22, 3116-3126. 
MacKenzie, L., Beuzenberg, V., Holland, P., McNabb, P., Selwood, A., 2004. Solid phase adsorption toxin tracking (SPATT): a new monitoring tool that simulates the biotoxin contamination of filter feeding bivalves. Toxicon : official journal of the International Society on Toxinology 44, 901-918.

Marasigan, A.N., Sato, S., Fukuyo, Y., Kodama, M., 2001. Accumulation of a high level of diarrhetic shellfish toxins in the green mussel Perna viridis during a bloom of Dinophysis caudata and Dinophysis miles in Sapian Bay, Panay Island, the Philippines. Fish. Sci. 67, 994-996.

Morton, S.L., Moeller, P.D.R., Young, K.A., Lanoue, B., 1998. Okadaic acid production from the marine dinoflagellelate Prorocentrum belizeanum Faust isolated from the Belizean coral reef ecosystem. Toxicon $36,201-206$.

Nwankwo, D.I., 1991. A survey of the dinoflagellates of Nigeria. Armoured dinoflagellates of Lagos Lagoon and associated Tidal creeks. Nigerian Journal of Botany 4, 49-60.

Nwankwo, D.I., 1997. A first list of dinoflagellates (Pyrrhophyta) from Nigerian coastal waters (creek, estuaries lagoons). . Pol. Arch. Hydrobiol 44, 313-321.

Odokuma, L.O., Isirima, J.C., 2007. Distribution of cyanotoxins in aquatic environments in the Niger Delta. Afr. J. Biotechnol. 6, 2375-2385.

Pan, Y., Cembella, A.D., Quilliam, M.A., 1999. Cell cycle and toxin production in the benthic dinoflagellate Prorocentrum lima. Mar. Biol. 134, 541-549.

Paz, B., Riobó, P., Fernández, M.L., Fraga, S., Franco, J.M., 2004. Production and release of yessotoxins by the dinoflagellates Protoceratium reticulatum and Lingulodinium polyedrum in culture. Toxicon [Toxicon] 44, 251-258.

Pitcher, G.C., Calder, D., 2000. Harmful algal blooms of the southern Benguela Current: a review and appraisal of monitoring from 1989 to 1997. South Afr. J. Mar. Sci.-Suid-Afr. Tydsk. Seewetens. 22, 255271.

Pitcher, G.C., Franco, J.M., Doucette, G.J., Powell, C.L., Mouton, A., 2001. Paralytic shellfish poisoning in the abalone Haliotis midae on the west coast of South Africa. Journal of Shellfish Research 20, 895904.

Rundberget, T., Gustad, E., Samdal, I.A., Sandvik, M., Miles, C.O., 2009. A convenient and cost-effective method for monitoring marine algal toxins with passive samplers. Toxicon : official journal of the International Society on Toxinology 53, 543-550.

Suzuki, T., Watanabe, R., 2012. Shellfish toxin monitoring system in Japan and some Asian countries, in: Cabado, A.G., Vieites, J.M. (Eds.), New Trends in Marine and Freshwater Toxins: Food Safety Concerns. Nova Science Publishers Inc.

Taleb, H., Vale, P., Amanhir, R., Benhadouch, A., Sagou, R., Chafik, A., 2006. First detection of azaspiracids in mussels in north west Africa. J. Shellfish Res. 25, 1067-1070.

Taleb, H., Vale, P., Blaghen, M., 2003. Spatial and temporal evolution of PSP toxins along the Atlantic shore of Morocco. Toxicon 41, 199-205.

Vale, P., Rangel, I., Silva, B., Coelho, P., Vilar, A., 2009. Atypical profiles of paralytic shellfish poisoning toxins in shellfish from Luanda and Mussulo bays, Angola. Toxicon 53, 176-183. 
145 Wolfender, J.-L., Marti, G., Thomas, A., Bertrand, S., 2015. Current approaches and challenges for the 146 metabolite profiling of complex natural extracts. Journal of Chromatography A 1382, 136-164. Hess, P., 2014. Extended evaluation of polymeric and lipophilic sorbents for passive sampling of marine toxins. Toxicon : official journal of the International Society on Toxinology 91, 57-68.

150 Zendong, Z., McCarron, P., Herrenknecht, C., Sibat, M., Amzil, Z., Cole, R.B., Hess, P., 2015. High resolution mass spectrometry for quantitative analysis and untargeted screening of algal toxins in mussels and passive samplers. Journal of Chromatography http://dx.doi.org/10.1016/j.chroma.2015.08.064.

\section{3}




\section{Supplementary material}

Algal toxin profiles in Nigerian coastal waters (Gulf of Guinea) using passive sampling and

Zita Zendong ${ }^{1,3}$, Medina Kadiri ${ }^{2}$, Christine Herrenknecht ${ }^{3}$, Elisabeth Nezan $^{4}$, Antonia Mazzeo ${ }^{5}$, Philipp Hess ${ }^{1}$ *

162

${ }^{1}$ Ifremer, Laboratoire Phycotoxines, Rue de l'Ile d'Yeu, 44311 Nantes, France;

$167{ }^{5}$ Dipartimento di Farmacia, Università degli Studi di Napoli Federico II, via D. Montesano 49, 80131, 168 Napoli, Italia;

169

170

171

Figure S1: Comparison of the high-resolution mass spectrum of PTX2 in a sample from Bar Beach to the spectrum of a certified standard of PTX2.

Figure S2: Surface focus of a Lingulodinium polyedrum cell in ventro-antapical view, in ventro-apical view and, in dorso-apical view showing ornamentation of plates (ridges along the sutures and circular depressions). 

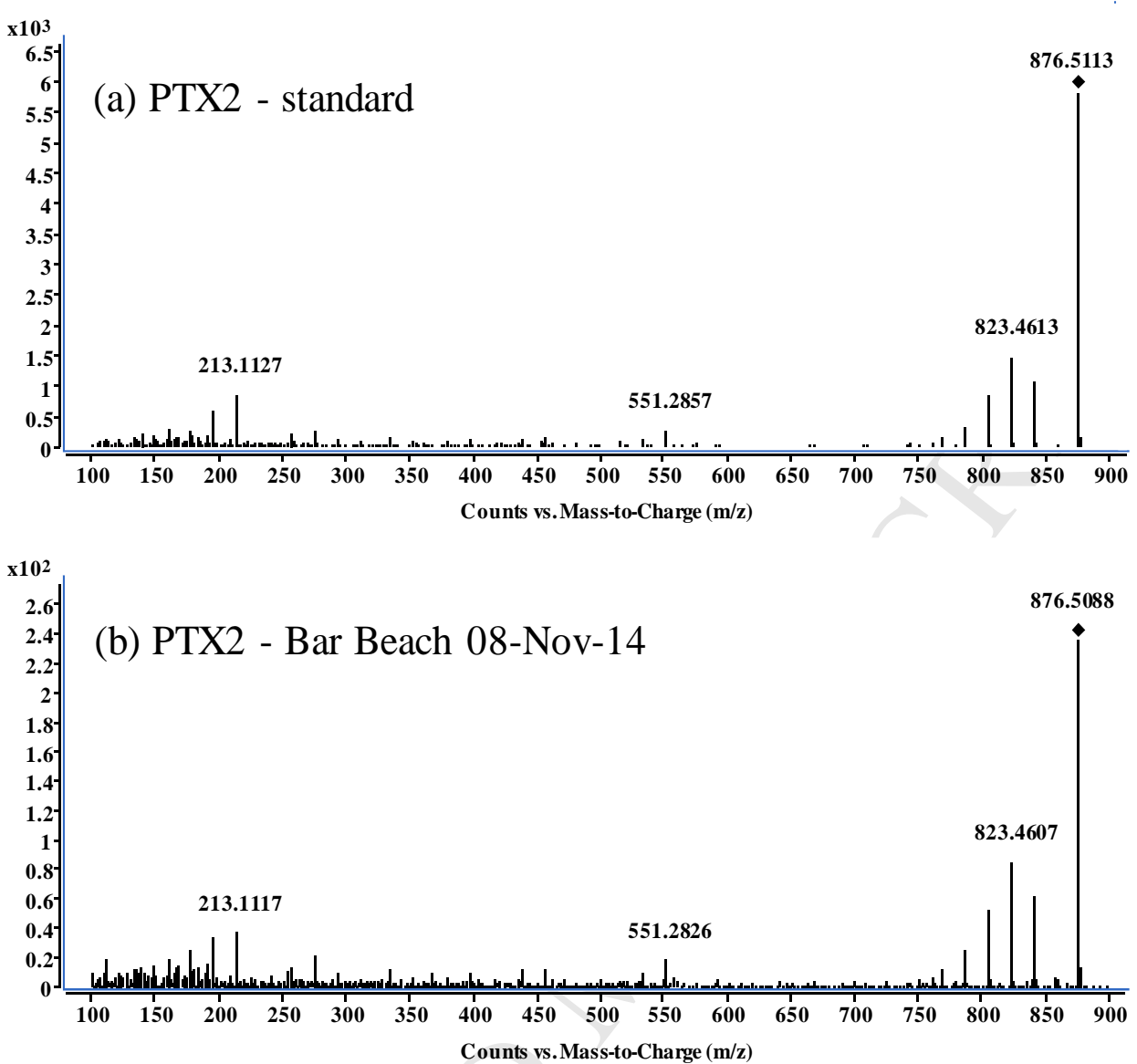

179 Figure S1: Comparison of the high-resolution mass spectrum of PTX2 in a sample from Bar Beach to the 180 spectrum of a certified standard of PTX2. 
182

183
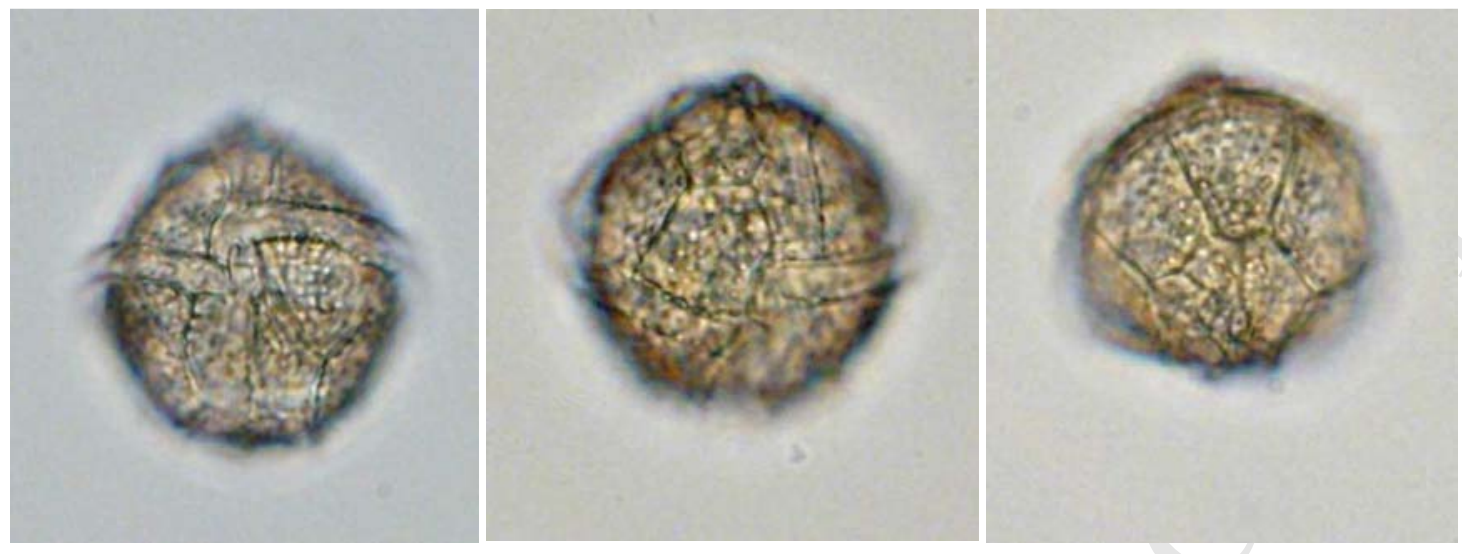

184 Figure S2: Surface focus of a Lingulodinium polyedrum cell in ventro-antapical view, in ventro-apical

185 view and, in dorso-apical view showing ornamentation of plates (ridges along the sutures and circular 186 depressions). 

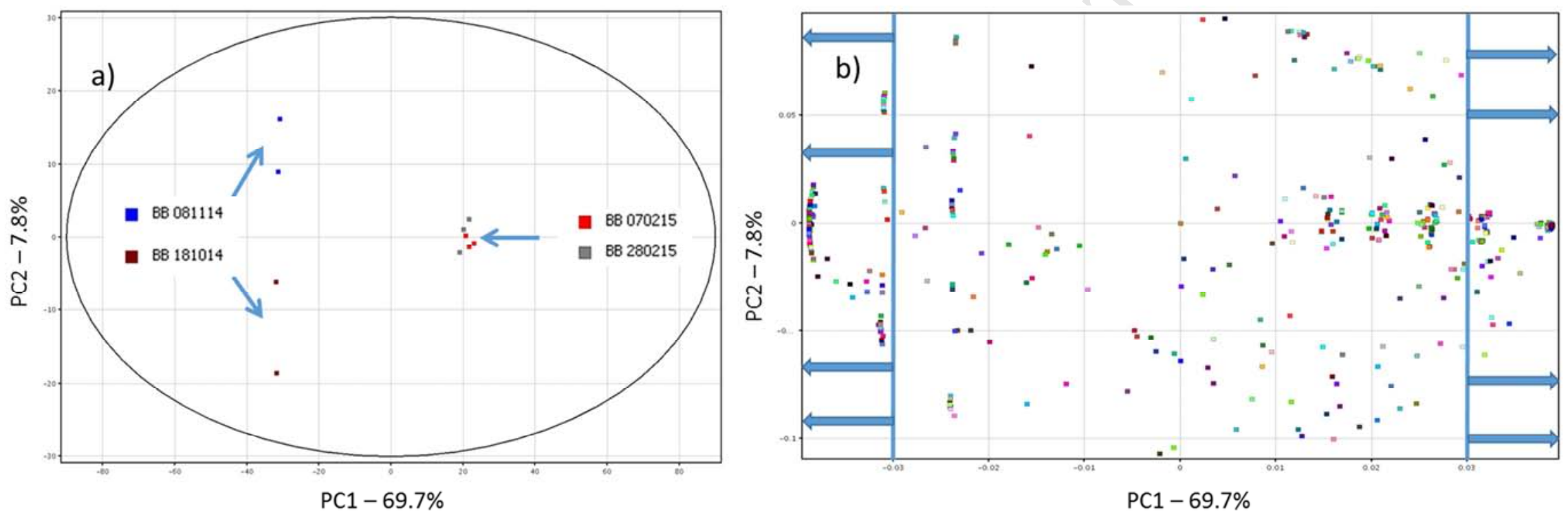

Figure S3. Principal Component Analysis (PCA) of passive samples taken at Bar Beach, Nigeria, in 2014/2015. The score plot (a) shows good separation of samples from October/November (left-hand side of graph) from those taken in February (right-hand side of graph). As this separation was almost exclusively on principal component 1 (accounting for almost $70 \%$ variability in the dataset), compounds most responsible for this separation are those that appear on the left- and right-hand side of the loadings plot (b). An arbitrary cut-off of 0.03 was chosen to select the most "separative" compounds. These compounds were subsequently screened against the Marine Natural Products Dictionary and results are given in Table 4 of the manuscript. 
Table S1. 170 compounds tentatively identified at Bar Beach on 08/11/2014

\begin{tabular}{|c|c|c|c|c|c|c|}
\hline Name & $m / z$ & Height & $\begin{array}{l}\text { Diff } \\
\text { (DB, } \\
\text { ppm) }\end{array}$ & $\underset{(\min )}{\text { RT }}$ & $\begin{array}{c}\text { Score } \\
\text { (DB) } \\
\%\end{array}$ & Mass \\
\hline $\begin{array}{l}\text { 1(10),5-Germacradien-4-ol; (1(10)E } \\
\text {,4a,5E )-form, O -(2-O - Acetyl-13-D- } \\
\text { glucopyranoside) }\end{array}$ & 444,296 & 14204 & $-0,87$ & 6,33 & 99,29 & 426,2621 \\
\hline 1,21 -Heneicosanediol & 328,3575 & 58944 & $-0,24$ & 5,30 & 99,96 & 328,3342 \\
\hline $\begin{array}{l}\text { 1,2-Benzenedicarboxylic acid; } \\
\text { Ditridecyl ester }\end{array}$ & 535,4124 & 33691 & $-0,5$ & 9,08 & 99,72 & 530,4338 \\
\hline $\begin{array}{l}1,7 \text {-Dihydroxy-2,5,10,14- phytatetraen- } \\
\text { 13-one; (2E ,5E } 7 \mathrm{r}, 10 \mathrm{E}) \text {-form }\end{array}$ & 303,2316 & 38682 & 0,73 & 5,32 & 99,63 & 320,2349 \\
\hline $\begin{array}{l}1,7 \text {-Dihydroxy-2,5,10,14- phytatetraen- } \\
13 \text {-one; }(2 \mathrm{E}, 5 \mathrm{E}, 7 \mathrm{r}, 10 \mathrm{E}) \text {-form }\end{array}$ & 303,2318 & 32854 & 0,11 & 6,57 & 99,99 & 320,2351 \\
\hline $\begin{array}{l}\text { 10-Aromadendranol; }(113,4 \mathrm{a}, 5 \\
\text { 13,6a,7ct,10ct)-form, O -[2- } \\
\left.\text { Methylpropanoyl-(i } i{ }^{1 / 2 * 2}\right)-3- \\
\text { Dfucopyranoside] }\end{array}$ & 438,3216 & 12346 & $-0,5$ & 6,80 & 99,76 & 438,2984 \\
\hline $\begin{array}{l}\text { 11,14-Dihydroxy-12-spongien-16- one; } \\
\text { (1113,14a)-form }\end{array}$ & 317,2111 & 93172 & 0,12 & 4,84 & 99,99 & 334,2144 \\
\hline $\begin{array}{l}\text { acid; }(8 \mathrm{R}, 11 \mathrm{R}, 12 \mathrm{R}, 13 \mathrm{E}, 15 \mathrm{~S}) \text {-form, } \\
\text { Et ester }\end{array}$ & 365,2687 & 26037 & $-0,07$ & 6,61 & 100 & 382,272 \\
\hline $\begin{array}{l}11,15 \text {-Dihydroxy-9-oxo-5,13- } \\
\text { prostadienoic acid; }(5 \mathrm{Z}, 8 \mathrm{R}, 11 \mathrm{R} \text {, }\end{array}$ & 366,2637 & 25639 & 0,49 & 2,22 & 99,8 & 366,2404 \\
\hline $\begin{array}{l}\text { oxo-25-scalaranoic acid; (12/3, 16/3)- } \\
\text { form, 22-Ac, Me ester }\end{array}$ & 506,3474 & 98047 & 0,39 & 4,59 & 99,83 & 506,3242 \\
\hline $\begin{array}{l}\text { 13,17-Epoxy-16-hydroxy-19-kauranoic } \\
\text { acid; (ent -16ct)-form, Me ester }\end{array}$ & 331,2268 & 64105 & $-0,03$ & 5,08 & 100 & 348,2301 \\
\hline 13-Docosenoic acid; (E)-form & 338,3419 & 22888 & $-0,41$ & 8,99 & 99,87 & 338,3186 \\
\hline $\begin{array}{l}\text { 14-Hydroxy-4,7,10,12,16,19- } \\
\text { docosahexaenoic acid; }(4 Z, 7 Z, 10 Z \\
\text {,12E } 14 ?, 16 Z, 19 Z) \text {-form }\end{array}$ & 321 & 37561 & $-0,73$ & 6,48 & 99,59 & 344,2354 \\
\hline $\begin{array}{l}\text { 15,17-Epoxy-15,17-dihydroxy-16- } \\
\text { isocopalanoic acid; (13aH ,14aH, } \\
\text { 15a,1713)-form, Di-Ac, Me ester }\end{array}$ & 468,296 & 49780 & $-0,97$ & 4,82 & 99,07 & 450,2622 \\
\hline $\begin{array}{l}\text { A15-Anhydrothyrsiferol; } 10 \text { - Epimer, } \\
\text { A }\end{array}$ & 586,33 & 18533 & 0,33 & 7,44 & 99,86 & 586,3067 \\
\hline $\begin{array}{l}16,24 \text {-Epoxy-21,24,25-trihydroxy-17- } \\
\text { cheilanthen-19,25-olide; (24?, 25?)- } \\
\text { form }\end{array}$ & 452,3005 & 99390 & 0,41 & 4,73 & 99,84 & 434,2667 \\
\hline $\begin{array}{l}16,24-\text {-Epoxy-21,24,25-trihydroxy- } 17- \\
\text { cheilanthen-19,25-olide; }(24 ?, 25 ?)- \\
\text { form }\end{array}$ & 452,3007 & 35080 & $-0,1$ & 4,82 & 99,99 & 434,2669 \\
\hline $\begin{array}{l}\text { 17-Methyl-1,17-tricosadiene- } \\
4,6,8,10,12,14,16 \text {-heptol }\end{array}$ & 446,3472 & 26475 & 0,83 & 5,86 & 99,32 & 446,324 \\
\hline $\begin{array}{l}\text { 1-Amino-4, 12-tridecadien-2-ol; }\left(\mathrm{i}_{i}^{1} 1 / 2\right)- \\
\text { (E )-form, N ,O -Di-Ac }\end{array}$ & 278,2114 & 28107 & 0,11 & 3,70 & 99,99 & 295,2147 \\
\hline $\begin{array}{l}\text { 1-Bromo-4,6-eudesmanediol; } \\
\text { (113,4a,6a,713H )-form, 4,6-Di- Ac }\end{array}$ & 420,1945 & 201266 & $-0,35$ & 2,60 & 99,89 & 402,1607 \\
\hline 1H-Indole-5,6-diol; Di-Me ether, N-Me & 191,118 & 45686 & $-0,45$ & 1,99 & 99,92 & 191,0947 \\
\hline 1-O -Alkylglycero-3- phosphocholines; & 576,3786 & 34960 & 0,34 & 7,52 & 99,86 & 571,4000 \\
\hline
\end{tabular}




\begin{tabular}{|c|c|c|c|c|c|c|}
\hline Name & $m / z$ & Height & $\begin{array}{l}\text { Diff } \\
\text { (DB, } \\
\text { ppm) }\end{array}$ & $\underset{(\min )}{\text { RT }}$ & $\begin{array}{c}\text { Score } \\
\text { (DB) } \\
\%\end{array}$ & Mass \\
\hline \multicolumn{7}{|l|}{$\begin{array}{l}\text { 1- Hexadecylglycero-3- } \\
\text { phosphocholine, 2-Benzyl ether }\end{array}$} \\
\hline $\begin{array}{l}\text { 2-(Aminomethyl)-2-propenoic acid; } \mathrm{N} \text { - } \\
\text { (2-Hydroxyhexadecanoyl), Me ester }\end{array}$ & 370,2951 & 19604 & 0,35 & 7,35 & 99,90 & 369,2878 \\
\hline $\begin{array}{l}\text { 2-(Aminomethyl)-2-propenoic acid; N- } \\
\text { (2-Oxohexadecanoyl), Me ester }\end{array}$ & 350,2691 & 129147 & $-0,44$ & 2,71 & 99,84 & 367,2724 \\
\hline $\begin{array}{l}2 \text {-(Aminomethyl)-2-propenoic acid; } \mathrm{N}- \\
\text { Hexadecanoyl }\end{array}$ & 322,2739 & 88009 & 0,4 & 3,82 & 99,88 & 339,2772 \\
\hline $\begin{array}{l}\text { 2,3,4,9-Tetrahydro-1H -pyrido }[3,4-\mathrm{b} \\
\text { ]indol-1-one; } 6 \text {-Methoxy }\end{array}$ & 199,0868 & 148648 & $-0,98$ & 1,73 & 99,57 & 216,0901 \\
\hline $\begin{array}{l}2,3,5,14,20,22,26 \text { - Heptahydroxyergost- } \\
7 \text {-en-6-one }\end{array}$ & 510,3429 & 72813 & $-0,63$ & 5,44 & 9,56 & 510,3196 \\
\hline $2,3,5,14,20,22,26-$ Heptahydroxyergost- & & & & & & \\
\hline $\begin{array}{l}\text { 7-en-6-one; }(213,313,513,14 \mathrm{a}, 20 \mathrm{R}, 22 \mathrm{R} \\
24 ?, 25 \mathrm{R}) \text {-form }\end{array}$ & 510,3419 & 36288 & $-0,05$ & & 00 & 510,3193 \\
\hline $\begin{array}{l}\text { 2,3'-Iminobispropanoic acid; }\left(\mathrm{i}_{i}{ }^{1 / 2}\right)- \\
\text { form, Di-Et ester, } \mathrm{N}-\mathrm{Ac}\end{array}$ & 242,1386 & 39061 & 0,3 & 3,13 & 99,95 & 259,1419 \\
\hline $2,4,6,6$-Tetrahydroxy-4'- & & & & & & \\
\hline $\begin{array}{l}\text { methylbenzophenone-2-carboxylic acid; } \\
\text { 2',6-Di-Me ether, Me ester }\end{array}$ & 329,1021 & 34581 & $-0,34$ & 3,66 & 99,91 & 346,1054 \\
\hline $\begin{array}{l}\text { 2,4,6-Tribromophenol; 4- } \\
\text { Methylbenzenesulfonyl }\end{array}$ & 486,8214 & 23862 & $-0,94$ & 2,95 & 99,08 & 481,8427 \\
\hline $\begin{array}{l}\text { 2,6,10-Farnesatrien-1-oic acid; } 6 \mathrm{~S}, 7 \mathrm{~S} \\
\text { :10R } 11 \text {-Diepoxide, Me ester }\end{array}$ & 300,2169 & 762 & 0,13 & 5,21 & 99,99 & 282,1831 \\
\hline 22,25 -Epoxy-24-methylfurostane- & & & & & & \\
\hline $\begin{array}{l}\text { 2,3,11,20-tetrol; (2ct,3ct,5ct,1113, } \\
1613,20 \mathrm{R}, 22 \mathrm{~S}, 24 \mathrm{~S}) \text {-form, 3-Ac }\end{array}$ & 543,3288 & 21999 & 0,73 & 5,29 & 99,4 & 520,3396 \\
\hline $\begin{array}{l}\text { 24-Methyl-16-pentacosene-2, 4-diyr } \\
\text { 1,6-diol }\end{array}$ & 303313 & 39095 & $-0,66$ & 8,80 & 99,62 & 388,3344 \\
\hline $\begin{array}{l}25 \text {-Methyl-1,25- hentriacontadiene- } \\
4,6,8,10,12,14,16,18,20,22,24-\text { undecol }\end{array}$ & 640,4633 & 19787 & $-0,48$ & 2,92 & 99,7 & 622,4295 \\
\hline 2-Amino-1,3,4,5- octadecanetetrol & 334,2953 & 70164 & $-0,45$ & 4,64 & 99,85 & 333,2881 \\
\hline $\begin{array}{l}\text {-Amino-1,3,4-hexadecanetriol; }(2 \mathrm{~S}, 3 \mathrm{R} \\
\mathrm{4S}) \text { - form }\end{array}$ & 290,2689 & 70470 & 0,2 & 4,65 & 99,98 & 289,2616 \\
\hline $\begin{array}{l}\text { 2-Amino-1,3-octadecanediol; }(2 \mathrm{R}, 3 \mathrm{~S} \\
\text { form, N,O,O-Tri-Ac }\end{array}$ & 410,3266 & 19374 & $-0,01$ & 7,17 & 100 & 427,3298 \\
\hline $\begin{array}{l}\text { 2-Amino-14-methyl-1,3,4- } \\
\text { pentadecanetriol }\end{array}$ & 290,2691 & 142823 & $-0,42$ & 2,96 & 99,89 & 289,2618 \\
\hline $\begin{array}{l}\text { 2-Amino-3-hydroxy-4- octadecene-1- } \\
\text { sulfonic acid }\end{array}$ & 708,502 & 22708 & $-0,94$ & 2,23 & 99,29 & 363,2447 \\
\hline $\begin{array}{l}\text { 2-Amino-4-octadecene-1,3- diol; } \\
(2 ?, 3 ?, 4 \text { ?)-form }\end{array}$ & 282,2793 & 42655 & $-0,56$ & 8,36 & 99,79 & 299,2826 \\
\hline $\begin{array}{l}\text { 2-Azetidinecarboxylic acid; (R ) -form, } \\
\text { N -Benzyl, Me ester }\end{array}$ & 223,1441 & 45912 & $-0,14$ & 2,16 & 99,99 & 205,1103 \\
\hline $\begin{array}{l}\text { 2-Ethyl-11-methoxy-3-methyl-3H - } \\
{[1,6] \text { naphthyridino[6,5,4-def ] }} \\
\text { quinoxaline }\end{array}$ & 279,1606 & 315814 & $-0,69$ & 9,86 & 99,7 & 279,1374 \\
\hline $\begin{array}{l}\text { 2-Hydroxy-10-oxo-4, } 10 \text {-seco-4, } \\
\text { 13(15),17-spatatrien-12-al }\end{array}$ & 299,2008 & 64485 & $-0,69$ & 6,37 & 99,66 & 316,2041 \\
\hline $\begin{array}{l}\text { 2-Methyl-1,16-dithiocyanato- 8- } \\
\text { hexadecanol }\end{array}$ & 370,2346 & 636724 & $-0,03$ & 1,94 & 100 & 370,2113 \\
\hline 2-Oxohexadecanoic acid; Me ester, (Z )- & 282,2428 & 73942 & $-0,03$ & 2,94 & 100 & 299,2461 \\
\hline
\end{tabular}




\begin{tabular}{|c|c|c|c|c|c|c|}
\hline Name & $m / z$ & Height & $\begin{array}{l}\text { Diff } \\
\text { (DB, } \\
\text { ppm) }\end{array}$ & $\begin{array}{c}\text { RT } \\
(\mathbf{m i n})\end{array}$ & $\begin{array}{c}\text { Score } \\
\text { (DB) } \\
\%\end{array}$ & Mass \\
\hline \multicolumn{7}{|l|}{ oxime } \\
\hline 3-(12-Nitrododecyl)pyridine & 310,2488 & 164095 & 0,38 & 3,54 & 99,91 & 292,215 \\
\hline $\begin{array}{l}3(20) \text {-Phytene-1,2-diol; }(2 ?, 7 ?, 11 ?)(1)- \\
\text { form, Di-Ac }\end{array}$ & 397,3311 & 52692 & 0,26 & 8,29 & 99,94 & 396,3239 \\
\hline $\begin{array}{l}\text { 3-(2-Hydroxyethyl)-6- prenylindole; } \\
\text { Aldehyde, oxime }\end{array}$ & 243,149 & 146928 & 0,67 & 3,72 & 99,77 & 242,1418 \\
\hline $\begin{array}{l}\text { 3-(3-Oxo-1-nonadecenyl) } \\
\text { oxiranecarboxylic acid }\end{array}$ & 367,2845 & 65781 & $-0,68$ & 6,33 & 99,63 & 366,2773 \\
\hline $\begin{array}{l}\text { 3,11-Dihydroxy-15-cembren-6- one; } \\
(1 \mathrm{R}, 3 \mathrm{R}, 4 \mathrm{R}, 8 \mathrm{~S}, 11 \mathrm{R}, 12 \mathrm{R})-\text { form }\end{array}$ & 307,2634 & 43991 & $-0,68$ & 9,02 & 99,67 & 324,2667 \\
\hline $\begin{array}{l}\text { 3,24-Dihydroxy-24-methyllanost- 8-en- } \\
\text { 30-oic acid; }(313,24 \text { ?)-form }\end{array}$ & 511,3757 & 36745 & 0,19 & 8,68 & 99,96 & 488,3865 \\
\hline $\begin{array}{l}3,4,6,24 \text {-Tetrahydroxycholest- } 8(14) \text {-en- } \\
15-\text {-one; }(3 \mathrm{i}, 43,5 \mathrm{ct}, 6 \mathrm{a}, 25 \mathrm{~S}) \text {-form }\end{array}$ & 448,3425 & 48064 & $-0,77$ & 7,81 & 99,41 & 448,3192 \\
\hline $\begin{array}{l}3,5 \text {-Dihydroxy-6,7-megastigmadien-9- } \\
\text { one; (3S } 5 \mathrm{~S}, 7 \mathrm{R} \text { ax)-form }\end{array}$ & 224,1645 & 127638 & 0,16 & 3,61 & 99,99 & 224,1412 \\
\hline $\begin{array}{l}\text { 3,6-Epidioxy-6-methoxy-4,16,18- } \\
\text { eicosatrienoic acid }\end{array}$ & 349,2372 & 40176 & 0,25 & 6,35 & 99,95 & 366,2405 \\
\hline $\begin{array}{l}\text { 3,7,11-Cembratrien-15-ol; (1S ,3E ,7E } \\
\text {,11E )-form, O -(6-O - Acetyl-13-D- } \\
\text { galactopyranoside) }\end{array}$ & 494,348 & 28402 & $-0,86$ & 8,11 & 99,21 & 494,3248 \\
\hline $\begin{array}{l}\text { 3-Hydroxy-11-oxo-12-oleanen-30- oic } \\
\text { acid; (3i3,183)-form, 3-O-13- } \\
\text { DGlucuronopyranoside }\end{array}$ & 646,3948 & 29679 & 0,29 & 2,88 & 99,89 & 646,3715 \\
\hline $\begin{array}{l}\text { 3-Hydroxycholan-24-oic acid; (3ct, } \\
\text { 513)-form, Glycine amide }\end{array}$ & 416,3163 & 48077 & $-0,93$ & 7,81 & 99,18 & 433,3196 \\
\hline $\begin{array}{l}\text { 3-Hydroxypregn-5-en-20- one; } \\
(313,13 \mathrm{ct}, 17 \mathrm{ct}) \text {-form, Ac }\end{array}$ & 358,2738 & 80308 & 0,59 & 4,35 & 99,72 & 358,2506 \\
\hline $\begin{array}{l}\text { 3-Hydroxypregn-5-en-20- one; } \\
(313,17 \mathrm{ct}) \text {-form, Ac }\end{array}$ & 341,2477 & 16660 & $-0,41$ & 6,58 & 99,87 & 358,2509 \\
\hline $\begin{array}{l}\text { 3-Hydroxyundecanoic acid; ( )-form, O } \\
\text {-[ct-L- Rhamnopyranosyl-(1--*3)-3- } \\
\text { hydroxyundecanoyl] }\end{array}$ & 550,3946 & 19328 & 0,72 & 2,55 & 99,41 & 532,3608 \\
\hline $\begin{array}{l}\text { 4,15:6,7-Diepoxy-1,8- dihydroxy-5- } \\
\text { hirsutanone; (1ct, } 4 \text { ?,63,7i3,83)-form, } 1 \text { - } \\
\text { (2- Hydroxyoctanoyl) }\end{array}$ & 405,227 & 58107 & 0,34 & 2,10 & 99,89 & 422,2303 \\
\hline $\begin{array}{l}\text { 4,7-Epoxy-3-hydroxy-8,12(18)- } \\
\text { dolabelladien-13-one }\end{array}$ & 301,2164 & 142942 & $-0,49$ & 6,04 & 99,83 & 318,2197 \\
\hline 4,8-Dimethyl-3-nonen-1-ol & 193,1563 & 13004 & 0 & 5,92 & 100 & 170,1671 \\
\hline $\begin{array}{l}\text { 4-Amino-3-hydroxybenzoic acid; } 2,7- \\
\text { Tetradecadienyl ester }(2 \mathrm{E}, 7 ?)\end{array}$ & 328,2271 & 80099 & 0,14 & 3,02 & 99,99 & 345,2303 \\
\hline $\begin{array}{l}4-H y d r o x y-16-h e p t a d e c e n e-5,7-\text { diyn-2- } \\
\text { one }\end{array}$ & 243,1742 & 17956 & 0,65 & 6,27 & 99,76 & 260,1775 \\
\hline $\begin{array}{l}\text { 4-Hydroxyphenylacetic acid; O -(3- } \\
\text { Methyl-2-butenyl), nitrile }\end{array}$ & 201,1383 & 34054 & 0,16 & 2,38 & 99,99 & 201,1153 \\
\hline 4-Nitrophenol; Octadecanoyl & 388,2848 & 206543 & $-0,48$ & 2,83 & 99,79 & 405,2881 \\
\hline $\begin{array}{l}\text { 5,6-Epoxy-3,11-dihydroxyergost- } 22- \\
\text { en-1-one; (3i3,5i3,63,11ct,22E , 24R )- } \\
\text { form, Di-Ac }\end{array}$ & 533,3241 & 28449 & $-0,7$ & 3,67 & 99,44 & 528,3455 \\
\hline $\begin{array}{l}5,6 \text {-Epoxy-7,10-cyclofarnesadien- 9-ol; } \\
(513,63,7 \mathrm{Z}, 9 \text { ?)-form }\end{array}$ & 236,2008 & 30610 & 0,27 & 2,22 & 99,96 & 236,1776 \\
\hline
\end{tabular}




\begin{tabular}{|c|c|c|c|c|c|c|}
\hline Name & $m / z$ & Height & $\begin{array}{l}\text { Diff } \\
\text { (DB, } \\
\text { ppm) }\end{array}$ & $\underset{(\min )}{\mathrm{RT}}$ & $\begin{array}{c}\text { Score } \\
\text { (DB) } \\
\%\end{array}$ & Mass \\
\hline 5,8-Epidioxyergosta-6,24(28)- dien-3-ol & 411,3257 & 34172 & 0,06 & 9,12 & 100 & 428,329 \\
\hline $\begin{array}{l}5,8 \text {-Epidioxyergosta-6, } 9(11), 22-\text { trien-3- } \\
\text { ol; (3i ,5ct,8a,22E ,24R )- form, O -3-D- } \\
\text { Glucopyranoside }\end{array}$ & 589,3741 & 301379 & $-0,81$ & 3,40 & 99,19 & 588,3667 \\
\hline $\begin{array}{l}\text { 5-Cyclohexene-1,2,3,4-tetrol; (1RS } \\
\text {,2RS ,3SR ,4RS )-form, Tetra-Ac }\end{array}$ & 297,0971 & 57968 & $-0,62$ & 1,87 & 99,73 & 314,1004 \\
\hline $\begin{array}{l}\text { 6,13-Epoxy-4(18)-euncellene-3,8, 9,12- } \\
\text { tetrol; (3a,6ct,83,9i3,12i3,13ct )-form, } \\
\text { 12-Butanoyl, 3-Ac }\end{array}$ & 466,3167 & 132888 & $-0,9$ & 5,07 & 99,18 & 466,2935 \\
\hline $\begin{array}{l}6,13 \text {-Epoxy-4(18)-eunicellene-7,8,9,12- } \\
\text { tetrol }\end{array}$ & 354,2644 & 12350 & 0,62 & 6,63 & 99,7 & 354,2404 \\
\hline $\begin{array}{l}6,13 \text {-Epoxy-4(18)-eunicellene- } 8,9,12- \\
\text { triol; (6ct,8ctOH,9i,12ctOH } 13 \text { a)-form }\end{array}$ & 321,2427 & 114679 & $-0,94$ & 6,63 & 99,34 & 338,246 \\
\hline $\begin{array}{l}\text { 6,13-Epoxy-4,8,9,12- eunicellanetetrol; } \\
\text { (4I } 6 \mathrm{a}, 8 \mathrm{ct}, 913,1213,13 \mathrm{ct}) \text {-form, } 9-\mathrm{Me} \\
\text { ether, } 12-\mathrm{Ac}\end{array}$ & 825,5718 & 835123 & 0,23 & 2,91 & 99,95 & 412,2824 \\
\hline $\begin{array}{l}\text { 6,13-Epoxy-8(19)-eunicellene-3,4, 9,12- } \\
\text { tetrol; (3ct,413,6a,913,123,13a )-form, } \\
3,4,12 \text {-Tri-Ac }\end{array}$ & 480,2953 & 39046 & 0,49 & 3 & 99,75 & 480,2721 \\
\hline $\begin{array}{l}\text { 7,11-Dihydroxy-13-spongien-16- one; } \\
(713,1113) \text {-form }\end{array}$ & 334,2379 & 44495 & $-0,83$ & 7,81 & 99,48 & 334,2147 \\
\hline 8-drimen-12,11-olide; & 277,1797 & 72298 & 0,49 & 5,74 & 99,84 & 294,183 \\
\hline $\begin{array}{l}\text { 7,14-Dihydroxy-15-nor-16- } \\
\text { isocopalanoic acid }\end{array}$ & 307,227 & 4 & $-0,67$ & 5,64 & 99,67 & 324,2303 \\
\hline $\begin{array}{l}\text { 7,8-Didehydro-13,13-carotene-3, } 3 \text { ',4,4'- } \\
\text { tetrol; (3S ,3'S } 4 \mathrm{~S}, 4 \text { 'S ) -form }\end{array}$ & 581,3992 & 17509 & $-0,53$ & 8,49 & 99,65 & 598,4025 \\
\hline $\begin{array}{l}9,11,15 \text {-Trihydroxyprost-13-enoic acid; } \\
\text { (8RS ,9SR ,11RS ,13E ,15 SR )-form, } \\
\text { Me ester }\end{array}$ & 353,2684 & 67371 & 0,76 & 5,85 & 99,52 & 370,2716 \\
\hline $\begin{array}{l}9 \text {-Hydroxy-5,7,11,14- eicosatetraenoic } \\
\text { acid; (5Z ,7E } 9 \mathrm{~S}, 11 \mathrm{Z}, 14 \mathrm{Z}) \text {-form, Me } \\
\text { ester }\end{array}$ & 317,2476 & 62084 & $-0,15$ & 5,78 & 99,98 & 334,2508 \\
\hline $\begin{array}{l}\text { 9-Hydroxy-7-hexadecenoic acid; (7E } \\
\text { 9S )-form, Ketone }\end{array}$ & 251 & 321 & $-0,62$ & 6,20 & 99,78 & 268,204 \\
\hline Ageline B & 532,3523 & 52722 & $-0,6$ & 7,48 & 99,59 & 531,3451 \\
\hline Amphiasterin C1;3-Epimer & 484,3034 & 112434 & $-0,11$ & 2,49 & 99,99 & 479,3247 \\
\hline Amphidinolide T2 & 452,3373 & 24688 & $-0,53$ & 6,64 & 99,72 & 452,314 \\
\hline Antillatoxin B & 548,3478 & 73840 & 0,92 & 6,65 & 99 & 565,3511 \\
\hline $\begin{array}{l}\text { Aplaminone; }(\mathrm{R}) \text {-form, A9' - Isomer(E } \\
-)_{1} \text { '-hydroxy }\end{array}$ & 8 & 0 & 4 & 3,40 & 100 & 34 \\
\hline $\begin{array}{l}\text { Aplysia MIP-related peptides; GAPRFI } \\
\text { amide }\end{array}$ & 641,3888 & 16326 & $-0,96$ & 5,12 & 98,77 & 658,3921 \\
\hline Aspergillamide $\mathrm{A}$ & 492,2967 & 10636 & 0,55 & 6,92 & 99,69 & 474,2628 \\
\hline Batzellaside A & 314,2691 & 30268 & $-0,34$ & 7,98 & 99,92 & 331,2724 \\
\hline Belamide A & 622,3959 & 17749 & 0,71 & 7,48 & 99,36 & 604,362 \\
\hline Bengazole Z; O 6- Heneicosanoyl & 629,4136 & 191826 & $-0,03$ & 2,74 & 100 & 606,4244 \\
\hline Biliverdin IX6; Di-Me ester & 593,2762 & 16779 & $-0,51$ & 8,79 & 99,67 & 610,2794 \\
\hline Chaetoglobosin A; 19-Deoxy, 20-deoxo & 481,2854 & 26963 & $-0,87$ & 6,93 & 99,18 & 498,2887 \\
\hline $\begin{array}{l}\text { Chotest-9(1)-ene-3,6,22-triol; }(3 \mathrm{i}-\mathrm{a} \text {-22R )-form, 22-Ac, 3,6-di-O - }\end{array}$ & 638,303 & 91823 & $-0,5$ & 4,70 & 99,67 & 620,2692 \\
\hline
\end{tabular}




\begin{tabular}{|c|c|c|c|c|c|c|}
\hline Name & $m / z$ & Height & $\begin{array}{l}\text { Diff } \\
\text { (DB, } \\
\text { ppm) }\end{array}$ & $\underset{(\min )}{\text { RT }}$ & $\begin{array}{c}\text { Score } \\
\text { (DB) } \\
\%\end{array}$ & Mass \\
\hline \multicolumn{7}{|l|}{ sulfate } \\
\hline $\begin{array}{l}\text { Cholestane-3,5,6,7-tetrol; }(313 \text {, } \\
\text { 5ct,6ct,7ct)-form, 3,6,7-Tri-Ac }\end{array}$ & 545,3833 & 50889 & 0,73 & 4,18 & 99,37 & 562,3865 \\
\hline $\begin{array}{l}\text { Clathrynamide } \mathrm{A} ; \mathrm{N}-(4-\mathrm{H} y d r o x y-1- \\
\text { methylpentyl) }\end{array}$ & 584,2541 & 34317 & 0,94 & 4,39 & 98,96 & 561,2648 \\
\hline Cochlioquinone A; 17-Methoxy & 545,311 & 19411 & $-0,1$ & 4,28 & 99,99 & 562,3142 \\
\hline $\begin{array}{l}\text { Cochlioquinone A; Hydroquinone, 11- } \\
\text { ketone }\end{array}$ & 532,327 & 43782 & $-0,28$ & 5,14 & 99,91 & 532,3038 \\
\hline Conicamine & 206,1178 & 56844 & 0,2 & 1,81 & 99,98 & 201,1391 \\
\hline Crambescidin 431 & 449,3123 & 36591 & $-0,21$ & 2,46 & 99,96 & 431,2785 \\
\hline Criamide A; N 1-Me & 682,4764 & 54752 & $-0,23$ & 2,75 & 99,93 & 682,4532 \\
\hline $\begin{array}{l}\text { Cyclo(tryptophylvalyl); (3S ,6S )-form, } \\
3,6 \text {-Bis(methylthio) }\end{array}$ & 377,1462 & 53953 & 0,68 & 1,97 & 99,61 & 377,1229 \\
\hline $\begin{array}{l}\text { Dideacetylraspacionin; } 10,28 \text { - Dihydro, } \\
\text { 103-hydroxy, 10,15- di-Ac }\end{array}$ & 594,437 & 38496 & $-0,96$ & 9,56 & 98,87 & 594,4137 \\
\hline Didemniserinolipid C; O 10 -Ac & 602,4022 & 20574 & 0,88 & 3,33 & 99,03 & 597,4235 \\
\hline Dolabelide B & 755,4944 & 23468 & $-0,47$ & 2,57 & 99,68 & 754,4871 \\
\hline $\begin{array}{l}\text { Ergosta-7,24(28)-diene-3,4,6,20, } 22- \\
\text { pentol; }(33,4 \mathrm{f} 3,5 \mathrm{a}, 6 \mathrm{a}, 20 ?, 22 ?) \text {-form, } \\
\text { 4,6-Di-Ac }\end{array}$ & 546,379 & 48858 & $-0,11$ & 6,36 & 99,98 & 546,3557 \\
\hline Ergostane-3,5,6,7,15-pentol & 471,3449 & 15081 & $-0,79$ & 4,62 & 99,36 & 466,3662 \\
\hline Exophilin A & 576,4109 & 38199 & $-0,42$ & 6,72 & 99,78 & 576,3876 \\
\hline Fasciospongide B & 466,28 & 94817 & $-0,13$ & 4,11 & 99,98 & 448,2462 \\
\hline Fellutamide $\mathrm{A}$; 1 -De & 556,3703 & 19846 & 0,39 & 2,12 & 99,82 & 555,363 \\
\hline Fungichromin & 671,4006 & 13344 & $-0,68$ & 5,83 & 99,37 & 670,3933 \\
\hline $\begin{array}{l}\text { Glutamic acid; (S)-form, N-(9Z, } 12 \mathrm{Z} \\
\text { 15Z -Octadecatrienoyl) }\end{array}$ & 815,5419 & 51820 & $-0,34$ & 3,50 & 99,89 & 407,2673 \\
\hline $\begin{array}{l}\text { Glycerol 1,2-dialkanoates; Glycerol 1- } \\
\text { hexadecanoate 2-tetradecanoate, 3-O - } \\
\text { 3-DGalactopyranoside }\end{array}$ & 725,5178 & 40381 & $-0,51$ & 2,99 & 99,63 & 702,5286 \\
\hline $\begin{array}{l}\text { Glycerol 1,2-dialkanoates; Glycerol 1- } \\
\text { (9Z-hexadecenoate) 2-tetradecanoate, 3- } \\
\text { O -?-DGalactopyranoside }\end{array}$ & 723,5021 & 32832 & $-0,46$ & 3,03 & 99,7 & 700,5129 \\
\hline $\begin{array}{l}\text { Glycerol 1-alkanoates; Glycerol 1- }(8,9- \\
\text { methylenehexadecanoate) }\end{array}$ & 365,2665 & 26024 & $-0,69$ & 5,76 & 99,64 & 342,2772 \\
\hline $\begin{array}{l}\text { Glycerol 1-alkanoates; Glycerol 1- } 9 \mathrm{Z}- \\
\text { octadecenoate), } 2-A c\end{array}$ & 381,3001 & 40190 & 0,54 & 6,87 & 99,74 & 398,303 \\
\hline $\begin{array}{l}\text { Glycerol 1-alkyl ethers; Glycerol 1- } \\
\text { tetradecyl ether }\end{array}$ & 288,2895 & 39536 & 0,62 & 5,17 & 99,76 & 288,2663 \\
\hline Halichomycin & 557,3951 & 18682 & $-0,29$ & 9,06 & 99,9 & 539,3612 \\
\hline Halimedalactone & 314,2116 & 49951 & $-0,5$ & 2,64 & 99,83 & 314,1884 \\
\hline Hemiasterlin & 526,3747 & 469332 & 0,8 & 3,06 & 99,28 & 526,3515 \\
\hline Hennoxazole A; 4-Deoxy & 498,3331 & 18685 & $-0,89$ & 4,09 & 99,14 & 498,3098 \\
\hline Hurghaperoxide & 405,3001 & 32507 & $-0,48$ & 8,05 & 99,79 & 422,3034 \\
\hline Kahalalide D & 613,3826 & 29507 & -1 & 2,70 & 98,77 & 595,3488 \\
\hline Kailuin A & 680,459 & 20500 & 0,35 & 3,18 & 99,83 & 697,4623 \\
\hline Kailuin B & 726,5014 & 96294 & $-0,3$ & 3,16 & 99,87 & 725,4941 \\
\hline Korormicin D & 430,295 & 131313 & 0,32 & 4,36 & 99,9 & 447,2983 \\
\hline Labiatamide A & 536,3218 & 15258 & 0,02 & 6,11 & 100 & 535,3145 \\
\hline
\end{tabular}




\begin{tabular}{|c|c|c|c|c|c|c|}
\hline Name & $m / z$ & Height & $\begin{array}{l}\text { Diff } \\
\text { (DB, } \\
\text { ppm) }\end{array}$ & $\begin{array}{c}\text { RT } \\
(\mathbf{m i n})\end{array}$ & $\begin{array}{c}\text { Score } \\
\text { (DB) } \\
\%\end{array}$ & Mass \\
\hline Lasonolide F; Et ester & 632,3797 & 168668 & $-0,63$ & 2,67 & 99,5 & 614,3459 \\
\hline $\begin{array}{l}\text { Manzamine A; (+)-form, } 6,3113- \\
\text { Dihydroxy, 32,33-dihydro }\end{array}$ & 600,3904 & 17080 & 0,66 & 3,27 & 99,46 & 582,3566 \\
\hline $\begin{array}{l}\text { Manzamine A; (+)-form, 8- Hydroxy, } \\
1 \mathrm{R}, 2,3,4 \text {-tetrahydro, N 2-Me }\end{array}$ & 600,4272 & 27839 & 0 & 2,08 & 100 & 582,3934 \\
\hline Martiriol & 522,3788 & 213917 & 0,21 & 4,32 & 99,95 & 522,3555 \\
\hline Melophlins; Melophlin K & 306,2424 & 31428 & 0,97 & 3,26 & 99,32 & 323,2457 \\
\hline Montipyridine & 274,1803 & 76954 & $-0,47$ & 2,47 & 99,86 & 291,1836 \\
\hline Muqubilin; (13R ,16R ,17R )- & 392,3159 & 32409 & $-0,06$ & 5,51 & 100 & 392,2927 \\
\hline Noroxopenlanfuran & 201,1272 & 12797 & 0,73 & 6,27 & 99,76 & 218,1305 \\
\hline Okadaic acid & 822,5002 & 10380 & $-0,62$ & 6,02 & 99,42 & 804,4665 \\
\hline Oscillatoxin A & 583,2873 & 20647 & 0,72 & 2,75 & 99,37 & 578,3087 \\
\hline Palinurine $\mathrm{A}$ & 440,2795 & 89875 & 0,16 & 3,66 & 99,97 & 457,2828 \\
\hline Pectenotoxin 1; Dihydro (?) & 876,5109 & 29177 & $-0,54$ & 6,57 & 99,53 & 876,4876 \\
\hline Pectinoacetal C & 535,3627 & 24008 & 0,45 & 7,13 & 99,76 & 534,3554 \\
\hline $\begin{array}{l}\text { Phosphatidylcholine; Glycerol 1,2 } \\
\text { didecanoate 3-phosphocholine }\end{array}$ & 583,4079 & 169882 & 0,44 & 2,81 & 99,76 & 565,3741 \\
\hline Pinnaic acid & 408,2299 & 79150 & 0,31 & 3,23 & 99,91 & 425,2332 \\
\hline $\begin{array}{l}\text { Plakortic acid*; 3-Epimer, 9, } 10- \\
\text { dihydro, Me ester }\end{array}$ & 319,2246 & 48230 & $-0,76$ & 7,17 & 99,6 & 314,2459 \\
\hline Pregnane-3,20-dione; 5 ct- form & 299,2371 & 62148 & $-0,65$ & 5,78 & 99,7 & 316,2404 \\
\hline Rhopaladin A; Debromo, 6- deoxy & 354,1347 & 44400 & 0,37 & 2,58 & 99,89 & 354,1115 \\
\hline Roserythrin & 578,3628 & 13687 & 0,14 & 4,80 & 99,98 & 578,3395 \\
\hline Saframycin A; 5ct-Hydroxy & 596,2345 & 31886 & 1 & 3,79 & 98,79 & 578,2007 \\
\hline $\begin{array}{l}\text { Sarcotragin A; N -De-(2- phenylethyl), } \\
\mathrm{N} \text { - (carboxymethyl) }\end{array}$ & 447,2857 & 80580 & $-0,85$ & 2,99 & 99,29 & 447,2625 \\
\hline $\begin{array}{l}\text { Scalusamide A; } 6^{\prime}, 7^{\prime}-\text { Didehydro(E-), } \\
8^{\prime}, 9 \text {-dihydro }\end{array}$ & 264,1960 & 37731 & $-0,74$ & 2,41 & 99,66 & 281,1993 \\
\hline Secoasbestinin & 392,2434 & 59078 & $-0,7$ & 2,09 & 99,58 & 392,2202 \\
\hline Semiplenamide E; $2 \mathrm{R} *, 3 \mathrm{~S} *$ - Epox & 434,3243 & 17707 & $-0,6$ & 5,99 & 99,67 & 411,3351 \\
\hline Siphonarin A; 3R -Alcohol & 491,3001 & 27544 & 0,38 & 6,53 & 99,84 & 508,3034 \\
\hline $\begin{array}{l}\text { Solanapyrone B; } 73 \text {-Hydroxy, } 4 \text { - } \\
\text { demethoxy, } 4 \text { '-[(2- } \\
\text { hydroxyethyl)amino], 1-aldehyde }\end{array}$ & 365,2073 & 42412 & $-0,71$ & 2,49 & 99,61 & 347,1735 \\
\hline 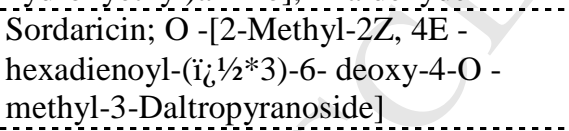 & 618,3632 & 12711 & 0,85 & 2,57 & 99,1 & 600,3293 \\
\hline $\begin{array}{l}\text { Stigmast-5-en-3-ol; }(313,24 \mathrm{R}) \text { - form, O } \\
\left.\text {-[3-D-Glucopyranosyl-( } \mathrm{i}_{i} \mathrm{1} / 2 * 4\right) \text {-ct-L- } \\
\text { arabinopyranoside] }\end{array}$ & 709,4880 & 210398 & 0,8 & 2,52 & 99,11 & 708,4807 \\
\hline $\begin{array}{l}\text { Stigmast-5-en-3-ol; (313,24R )- form, O } \\
\left.\text {-[ct-Rhamnopyranosyl-(1 ï }{ }^{1 / 2} 2^{*} 5\right) \text {-ct-L- } \\
\text { arabinofuranoside] }\end{array}$ & 692,5090 & 587162 & 0,8 & 2,77 & 99,12 & 692,4858 \\
\hline $\begin{array}{l}\text { Stigmasta-7,22-diene-2,3,5,6,9, } 11,19- \\
\text { heptol; }(2 \mathrm{a}, 3 \mathrm{i} 3,5 \mathrm{ct}, 63,11 \mathrm{ct}, 24 \mathrm{~S}) \text {-form, } \\
\text { 11,19-Di-Ac }\end{array}$ & 575,3574 & 40356 & 0,83 & 3,25 & 99,15 & 592,3606 \\
\hline $\begin{array}{l}\text { Stigmastane-3,4,6,15,16,29- hexol; } \\
(313,4 \mathrm{f} 3,5 \mathrm{ct}, 6 \mathrm{ct}, 1513,163,24 \mathrm{R}) \text {-form }\end{array}$ & 519,3661 & 68075 & $-0,96$ & 2,97 & 99,01 & 496,3769 \\
\hline Stigmastane-3,5,6,15,29-pentol; & 477,3578 & 24274 & $-0,7$ & 8,94 & 99,48 & 494,3611 \\
\hline
\end{tabular}




\begin{tabular}{|c|c|c|c|c|c|c|}
\hline Name & $m / z$ & Height & $\begin{array}{c}\text { Diff } \\
\text { (DB, } \\
\text { ppm) }\end{array}$ & $\begin{array}{c}\text { RT } \\
(\mathbf{m i n})\end{array}$ & $\begin{array}{c}\text { Score } \\
\text { (DB) } \\
\% \\
\end{array}$ & Mass \\
\hline \multicolumn{7}{|l|}{$\begin{array}{l}(3 \mathrm{i} 3,5 \mathrm{a}, 63,15 \mathrm{a}, 24 \mathrm{R}) \text {-form, } 29- \\
\text { Carboxylic acid }\end{array}$} \\
\hline Stolonic acid A & 434,3268 & 20806 & $-0,73$ & 7,80 & 99,49 & 434,3035 \\
\hline Synechobactin A & 578,3756 & 20813 & 0,7 & 2,56 & 99,42 & 560,3417 \\
\hline Taurospongin $\mathrm{A}$ & 741,5078 & 78719 & 0,5 & 2,64 & 99,63 & 741,4846 \\
\hline Tedanolide & 628,3686 & 15008 & 0,9 & 4,97 & 98,98 & 610,3348 \\
\hline Theopederin A & 526,3010 & 22820 & 0,17 & 4,93 & 99,97 & 543,3043 \\
\hline Thorectandramine & 438,2052 & 85140 & $-0,28$ & 2,67 & 99,92 & 438,1819 \\
\hline Tumonoic acid A; Me ester & 336,2531 & 53235 & 0,54 & 4,37 & 99,77 & 353,2564 \\
\hline
\end{tabular}


First detection of OA, PTX2 and possible presence of DTX1 in African coastal marine environments.

Presence of Dinophysis caudata and Prorocentrum spp in seawater consistent with passive sampler findings.

HRMS analysis used for chemical profiling of marine environments using passive sampler.

Untargeted analysis pointed towards presence of a cyanobacteria community. 


\section{Ethical statement for}

\section{Algal toxin profiles in Nigerian coastal waters (Gulf of Guinea) using passive sampling and liquid chromatography coupled to mass spectrometry}

Zita Zendong ${ }^{1,3^{*}}$, Medina Kadiri ${ }^{2}$, Christine Herrenknecht ${ }^{3}$, Elisabeth Nézan ${ }^{4}$, Antonia Mazzeo ${ }^{5}$, Philipp Hess ${ }^{1}$.

${ }^{1}$ Ifremer, Laboratoire Phycotoxines, Rue de l'Ile d'Yeu, 44311 Nantes, France;

${ }^{2}$ Department of Plant Biology and Biotechnology, University of Benin, Benin City, Nigeria

${ }^{3}$ LUNAM, Université de Nantes, MMS EA2160, Faculté de Pharmacie, 9 rue Bias, 44035 Nantes, France;

${ }^{4}$ Ifremer, Station de Biologie Marine, BP 40537, F-29185 Concarneau Cedex, France ;

${ }^{5}$ Dipartimento di Farmacia, Università degli Studi di Napoli Federico II, via D. Montesano 49, 80131, Napoli, Italia;

This paper has not been published in or submitted to any other journal. No animals have been used in any of our experimentations.

On behalf of the authors, 